\title{
Article
}

\section{Cliff Retreat Contribution to the Littoral Sediment Budget along the Baltic Sea Coastline of Schleswig-Holstein, Germany}

\author{
Tanita Averes ${ }^{1, * \mathbb{C}}$, Jacobus L. A. Hofstede ${ }^{2}$, Arfst Hinrichsen ${ }^{3}$, Hans-Christian Reimers ${ }^{4}$ and Christian Winter ${ }^{1} \mathbb{D}$ \\ 1 Institute of Geosciences, Coastal Geology and Sedimentology, Kiel University, 24118 Kiel, Germany; \\ christian.winter@ifg.uni-kiel.de \\ 2 Schleswig-Holstein Ministry of Energy Transition, Agriculture, Environment, \\ Nature and Digitization (MELUND), 24105 Kiel, Germany; jacobus.hofstede@melund.landsh.de \\ 3 Schleswig-Holstein State Office for Coastal Protection, National Park and Marine Protection (LKN-SH), \\ 25813 Husum, Germany; arfst.hinrichsen@lkn.landsh.de \\ 4 State Agency for Agriculture, Environment and Rural Areas (LLUR), 24220 Flintbek, Germany; \\ hans-christian.reimers@llur.landsh.de \\ * Correspondence: tanita.averes@ifg.uni-kiel.de
}

check for updates

Citation: Averes, T.; Hofstede, J.L.A.; Hinrichsen, A.; Reimers, H.-C.; Winter, C. Cliff Retreat Contribution to the Littoral Sediment Budget along the Baltic Sea Coastline of Schleswig-Holstein, Germany. J. Mar. Sci. Eng. 2021, 9, 870. https:// doi.org/10.3390/jmse9080870

Academic Editor: Alfredo

L. Aretxabaleta

Received: 14 July 2021

Accepted: 9 August 2021

Published: 12 August 2021

Publisher's Note: MDPI stays neutral with regard to jurisdictional claims in published maps and institutional affiliations.

Copyright: (c) 2021 by the authors. Licensee MDPI, Basel, Switzerland. This article is an open access article distributed under the terms and conditions of the Creative Commons Attribution (CC BY) license (https:// creativecommons.org/licenses/by/ $4.0 /)$.

\begin{abstract}
Mobile coastal sediments, such as sand and gravel, build up and protect wave-dominated coastlines. In sediment-starved coastal environments, knowledge about the natural sources and transport pathways of those sediments is of utmost importance for the understanding and management of coastlines. Along the Baltic Sea coast of Schleswig-Holstein (Germany), the retreat of active cliffsmade of cohesive Pleistocene deposits-supplies a wide size range of sediments to the coastal system. The material is reworked and sorted by hydrodynamic forcing: the less mobile stones and boulders remain close to the source area; the finest sediments, mostly clay and silt, are transported offshore into areas of low energy; and the fractions of sand and fine gravels mostly remain in the nearshore zone, where they make up the littoral sediment budget. They contribute to the morphodynamic development of sandy coastlines and nearshore bar systems. Exemplarily for this coastal stretch and based on an extensive review of local studies we quantify the volume of the potential littoral sediment budget from cliff retreat. At an average retreat rate of $0.24 \mathrm{~m} \mathrm{yr}^{-1}\left(<0.1-0.73 \mathrm{~m} \mathrm{yr}^{-1}\right)$, the assessment indicates a weighted average sediment volume of $1.5 \mathrm{~m}^{3} \mathrm{yr}^{-1} \mathrm{~m}^{-1}\left(<0.1-9.5 \mathrm{~m}^{3} \mathrm{yr}^{-1} \mathrm{~m}^{-1}\right)$ per meter active cliff. For the whole area, this results in an absolute sediment budget $\mathrm{V}_{\mathrm{s} \text {,total }}$ of $39,000-161,000 \mathrm{~m}^{3} \mathrm{yr}^{-1}$. The accuracy of the results is limited by system understanding and data quality and coverage. The study discusses uncertainties in the calculation of littoral sediment budgets from cliff retreat and provides the first area-wide budget assessment along the sediment-starved Baltic Sea coastline of Schleswig-Holstein.
\end{abstract}

Keywords: cliff retreat; littoral sediment; sediment budget; coastal protection; sediment-starved environment; Baltic Sea

\section{Introduction}

Sands and gravels are valuable resources in coastal zones. These mobile sediments characterize and stabilize sandy coastlines in wave-dominated environments and determine the littoral material transport [1-3]. In the context of global warming, and the associated sea-level rise and extreme weather events (precipitation, storms), the hydrodynamic pressure on the coasts increases [4-6]. This leads to enhanced erosion capacity along exposed coastlines. In areas with a limited supply of coast-stabilizing material, sediment deficits occur and the vulnerability of the coastlines increases [5].

The availability of coast-stabilizing sediments in the littoral environment depends on the natural sources, such as rivers, coastal cliffs, and seafloor sediments $[3,7,8]$. In this study, we focus on the sediment contribution from cohesive cliffs-soft-rock deposits with a high content of clay and silt $[9,10]$. 
The retreat of those cliffs is a natural process [2,11]. It is controlled by hydrodynamic impact-wind-induced waves and resulting currents, short-term water level fluctuations, long-term sea-level rise [2,11,12]; the resisting nature of the cliff material-its geological structure, geomechanical properties, lithological, and sedimentological composition [13,14]; and the beach and nearshore morphology $[15,16]$. The cliff retreat does not occur continuously but episodic or irregular $[17,18]$. Under the impact of marine forces, e.g., during storm surges, material is removed from the lower cliff face. This leads to steepening of the slope and, simultaneously, decreases the cliff stability, until mass movement occurs. The mobilized material creates a cliff dump or talus in front of the cliff toe [11,19].

During mobilization of the consolidated cliff material the bulk density decreases, which results in an increase in volume $[13,20]$. Subsequently, the volume of the exposed bulk material is reduced again as it is subject to reworking, sorting, and transport processes $[3,21]$. Atmospheric and marine influence initiate chemical and physical weathering as well as transport and sorting of the sediments [21,22]. Hereby, the carbonate contained is mostly removed [22,23].

The remaining siliciclastic sediment is sorted into different grain size fractions according to their behavior under hydrodynamic impact [3]: less mobile stones and boulders remain near the source area or relocate within short distances $[3,24,25]$. The finest sediments-mostly clay and silt-are transported in suspension and deposited in sheltered areas or deeper waters [26-28]. The fractions of sand and fine gravels feed the long- and cross-shore sediment transport in the littoral zone. With a temporary decrease in transport capacity, it comes to accumulation in potential sink areas, such as lowland beaches, sand spits, or nearshore bars. This may contribute to the preservation or even to a seaward shift of the current shoreline $[1,29,30]$. The volume of those mobile and potentially coast-stabilizing sands and gravels is hereafter referred to as the 'littoral sediment budget'.

A quantitative assessment of the littoral sediment budget is of vital importance for the coastal management, e.g., the planning and installation of coastal stabilization measures. This applies in particular in a sediment-starved system, where shoreline erosion determines the natural dynamics. As an example of a sediment-starved shoreline, in this study, we estimate the annual littoral sediment budget provided by the cliff retreat along the German Baltic Sea coastline of Schleswig-Holstein (S-H). Despite the known lack of sandy resources for shoreline preservation, comprehensive budgeting has not yet been performed for this area.

Based on an extensive literature review, we determine the amount of decalcified sand and gravels, eroded from the cliff sites, with a grain size range of 0.063-64 $\mathrm{mm}$. We further point out the uncertainties of this literature-based budget assessment due to data gaps, inaccurate measurements and methods, and the complexity of the system.

\section{Regional Setting}

The wave-dominated and micro-tidal Baltic Sea coast of the German federal state of Schleswig-Holstein has a reference length of $399 \mathrm{~km}$ (mainland: $328 \mathrm{~km}$; Fehmarn Island: $71 \mathrm{~km}$, excluding the Schlei inlet) [5]. The coastline is overall exposed to the NE, while the regional exposition of individual sections varies in all directions.

The geomorphology results from the deposition of glacial and interstadial sediments during the Pleistocene [31,32]. With the Holocene sea-level rise- the Littorina Transgression starting $\sim 8400 \mathrm{BP}$ in this area-the Pleistocene deposits were increasingly affected by marine forces $[26,33]$. The initiated processes of erosion, material transport, and accumulation led to the formation of the present-day appearance of alternating cohesive cliffs and coastal lowlands [26,34]. The active cliffs-potentially within reach of marine hydrodynamic forces - make up about $85 \mathrm{~km}(\sim 20 \%)$ of the current coastline [35], of which $\sim 57 \mathrm{~km}$ have been investigated by Ziegler and Heyen [36] regarding cliff retreat and material erosion (Figure 1a). During the last century, the cliffs experienced an average annual retreat of $\sim 0.2 \mathrm{~m} \mathrm{yr}^{-1}[8,36]$. The resulting qualitative and quantitative sediment supply to the littoral system depends on the local character of those cliffs. 


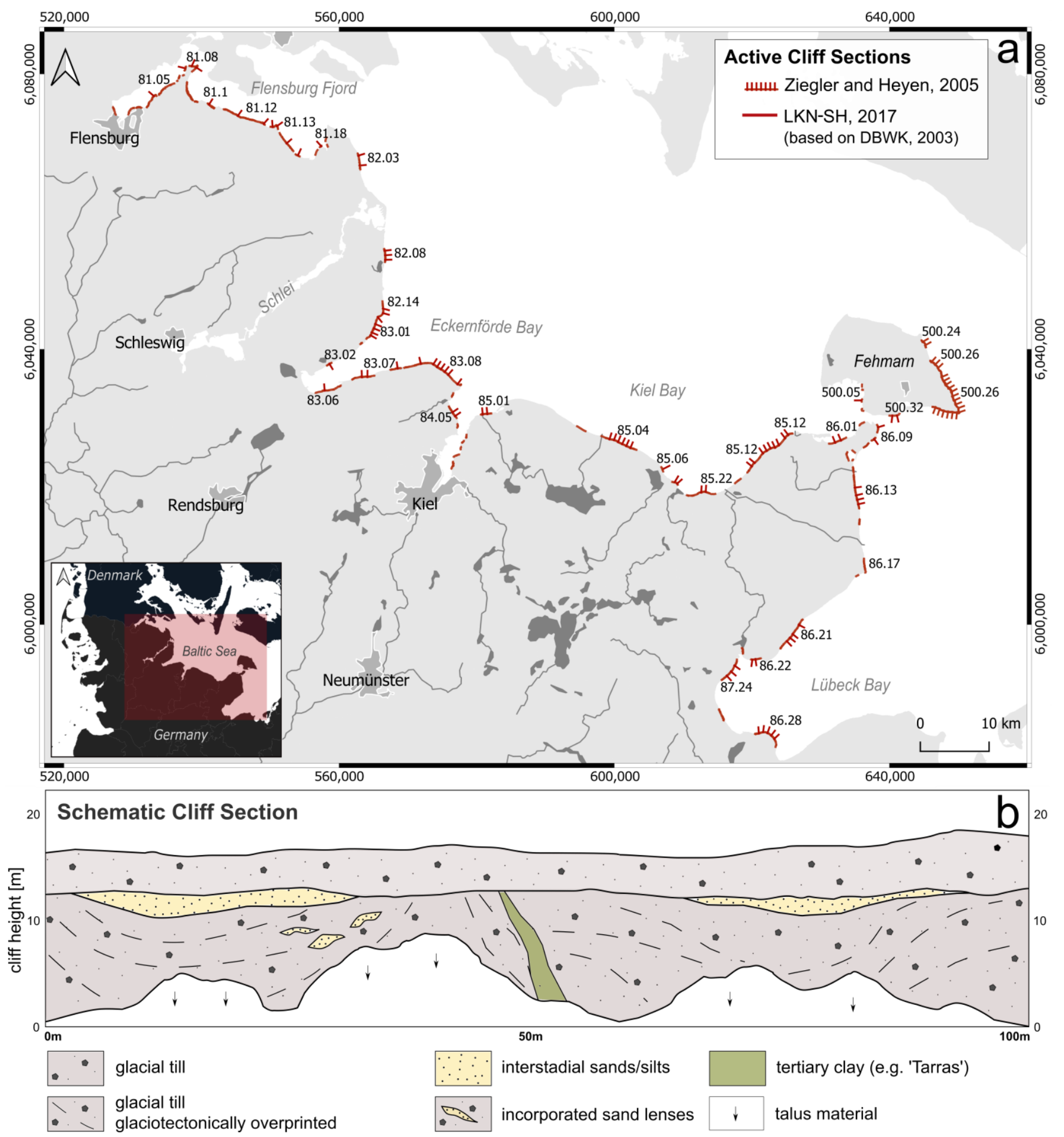

Figure 1. (a) Baltic Sea coastline of S-H, Germany, with active cliff sections defined by Ziegler and Heyen [36] and LKN$\mathrm{SH}$ [35] based on the digital map of federal waterways (DBWK 2003) [37]. Labels refer to the numbers of the coastal subsections where the cliffs are located (mainland: 81.01-86.32; Fehmarn Island: 500.01-500.32) [35]. (b) Schematic overview of a typical Pleistocene cliff deposit in the study area.

The cohesive cliffs along the Baltic Sea coastline have a highly variable geological and sedimentological character (Figure 1b) [26,38], which results from the nature of the material sources, the transport and the depositional conditions [39-41], and glaciotectonic influences during the latest Ice Ages (Weichselian, Saalian) [20,42]. The majority of the cliffs 
were formed in Weichselian morainic deposits, referred to as glacial till or boulder clay. In most areas, the glacial till can be distinguished into at least two geological complexes, which result from successive ice advances $[31,43,44]$. The till mainly appears in grey to brownish, massive, and compact layers [41]. With its clay- and silt-rich matrix and incorporated sand, pebbles, and boulders, it covers a very wide grain-size spectrum $[13,45]$. The proportions of the different sediment fractions can vary greatly within the individual layers of glacial till [45-47]. The till deposits are calcareous [23]. The carbonate is heterogeneously distributed within the matrix and stems from Cretaceous material, which was incorporated during glacial transport as fine particles, larger chunks ( $<20 \mathrm{~cm}$ diameter), or extended bands $[23,48]$.

Between and within the glacial till complexes, glaciolimnic silts, glaciofluvial sands, and gravels are present in the geological cliff succession $[26,34,38]$. Their deposition is associated with temporary recessions and subsequent advances of the glaciers [26,39]. Thereby, the material was overlain by another moraine deposit and partially incorporated $[39,45]$. While on most cliffs along the studied coastline the interstadial sediments only make up a minor part of the outcrops, there are a few exceptions: the cliffs of Dahmeshöved (86.17) and Schilksee (84.05), for example, are almost exclusively built of interstadial sands and gravels [8]. The cliff of western Holnis (81.08) consists mainly of glaciolimnic deposits [49].

Except for the uppermost glacial till complex, assigned to the latest ice advance, all underlying deposits were affected by glaciotectonic forces. Due to the repeated impact of overriding ice masses, the Pleistocene material is mostly overconsolidated and exhibits high dry bulk densities and high geotechnical cohesion $[13,45]$. The deposits also experienced tilting, folding, and thrusting in many areas $[23,50]$. At some cliff locations, e.g., at Stohl (83.03), Heiligenhafen (85.12), and along Fehmarn, this resulted in outcrops of older material, such as tertiary clay-so-called Tarras-and clay deposits from the Eem interglacial $[42,47,51]$.

Due to the irregular distribution of sedimentological and lithological components and the glaciotectonic imprint, the cliff deposits show high variability in their physical properties (e.g., dry bulk density, internal shear strength, and water absorption capacity) and, thus, react locally differently to hydrodynamic forces and environmental impacts $[13,14]$.

\section{Data and Methods}

\subsection{Origin and Use of Data}

The data basis of this work is a compilation of accessible literature concerning cliff retreat and the geological and sedimentological properties of the cohesive cliffs in the study area. This includes scientific publications as well as unpublished work (project data and reports, as well as Ph.D. and student theses).

For the assessment of the cliff retreat, we focused on three investigations that observed the spatial change of the upper cliff edge during different periods (Table A1). Kannenberg [8] provides the earliest data on this topic based on a comparison of comprehensive geodetic and cadastral surveys (1:2000) from around 1878 and 1950 (exact dates not available). A study by Ziegler and Heyen [36] compared two compilations of coastal surveys performed by the former Landesamt für Wasserhaushalt und Küsten (LW) at the scale of 1:2000 (1st survey 1949-1968, 2nd survey 1974-1987, supplementary measurements 1999-2002). A third unpublished analysis presents a comparison between the geodetic measurements from 1878 (Preußische Landesaufnahme; 1:25,000) and aerial photographs from 2016 (DOP20).

For the sediment budgeting, we use the data base of Ziegler and Heyen [36], who provide volume values on the annual material loss at individual cliff sections based on their retreat analyses (Table A2). Further, we included quantitative information about the grain size distribution, the carbonate content, and the thickness of the geological layers, if available (Table A2). The data were derived from local studies. For the majority of cliffs, no adequate local data were available on this concern. 


\subsection{Sediment Budget Assessment}

In the context of this study, the littoral sediment budget is calculated considering (a) the volumetric material erosion at the cliffs given by [36]; (b) the degree of decompaction of the highly compacted glacial material due to mobilization; and (c) the loss of carbonate and the fine siliciclastic sediment fractions $(<0.063 \mathrm{~mm})$ during reworking and transport processes. Due to the high heterogeneity of the coastline and the limited data coverage in the study area, this approach should be understood as an approximation or best guess of the littoral sediment budget.

The amount of eroded material at a cliff site per year is referred to as the erosional volume $\mathrm{V}_{\mathrm{e}}\left(\mathrm{m}^{3} \mathrm{yr}^{-1}\right)$ :

$$
\mathrm{V}_{\mathrm{e}}=\mathrm{LH} \mathrm{r}
$$

where $\mathrm{L}(\mathrm{m})$ is the length of the active cliff sections with a minimum height of $2 \mathrm{~m}$ and a minimum length of $50 \mathrm{~m}$ (status 1974); $\mathrm{H}(\mathrm{m}$ ) is the estimated average height between the lower and upper cliff edge; and $\mathrm{r}\left(\mathrm{m} \mathrm{y}^{-1}\right)$ is the annual retreat rate. The latter was determined as the spatial change of the upper cliff edge for time intervals between 1949 and 2002 - measured in one meter steps and averaged over the local cliff length [36].

The sum of $\mathrm{V}_{\mathrm{e}}$ of all individual cliff sites represents the total amount of eroded material $\mathrm{V}_{\mathrm{e}, \text { total }}$ in the study area per year.

The specific erosional volume $\mathrm{v}_{\mathrm{e}}$ describes the eroded material per meter active cliff:

$$
\mathrm{v}_{\mathrm{e}}=\frac{\mathrm{V}_{\mathrm{e}}}{\mathrm{L}}
$$

The degree of deconsolidation of the cohesive material during erosion has an impact on the resulting material volume. We calculate the specific bulk volume $\mathrm{vb}\left(\mathrm{m}^{3} \mathrm{yr}^{-1} \mathrm{~m}^{-1}\right)$ :

$$
\mathrm{v}_{\mathrm{b}}=\mathrm{v}_{\mathrm{e}} \mathrm{h} \quad\{1.5<\mathrm{h}<2\}
$$

where $\mathrm{h}$ is the bulk factor proposed by Seifert [20] for the prevailing cliff material.

For a simplified result presentation, an average bulk factor h1.75 is applied. For further calculations based on the bulk volume, the whole range of $h(1.5 ; 2)$ is considered.

The specific sediment budget vs $\left(\mathrm{m}^{3} \mathrm{yr}^{-1} \mathrm{~m}^{-1}\right)$ is quantified by including the geologicallithological and sedimentological information of the source material in the calculation.

$$
\mathrm{v}_{\mathrm{s}}=\mathrm{v}_{\mathrm{b}}(1-\mathrm{c}) \mathrm{n}
$$

where $\mathrm{c}$ is the fraction of carbonate and $\mathrm{n}$ is the fraction of siliciclastic material with a grain size range of $0.063-64 \mathrm{~mm}$.

Due to the high variability in geological structures, lithological and sedimentological properties, and the limited observational data in the study area, no generally valid average values can be determined for the variables $\mathrm{c}$ and $\mathrm{n}$. Hence, they are based on assumptions. At cliff sections where local information regarding the prevalence and thickness of the geological layers, grain size distribution, and carbonate content was available, it was included in the calculation of vs. For the areas without the corresponding information, the following assumptions were made to approximate vs in the best possible way:

1. The cliff sections are composed entirely of glacial till with a homogenous sediment composition;

2. The quantities of $\mathrm{c}$ and $\mathrm{n}$, given in local studies, set the value range of $\mathrm{c}$ and $\mathrm{n}$ for all cliffs in the study area.

The sum of all values of vs multiplied by the respective cliff lengths represents the final estimate of the total littoral sediment budget $V_{s, t o t a l}$ supplied to the nearshore system from all observed cliff sites along the Baltic Sea coast of S-H. 


\section{Results}

\subsection{Cliff Retreat}

The retreat of active cliffs has been the subject of several studies along the S-H coastline. These studies report estimates for the annual rates of retreat for individual cliff sections (Figure 2). The results refer to different periods. They are also based on data sets that have different levels of accuracy and were obtained by different methodologies.

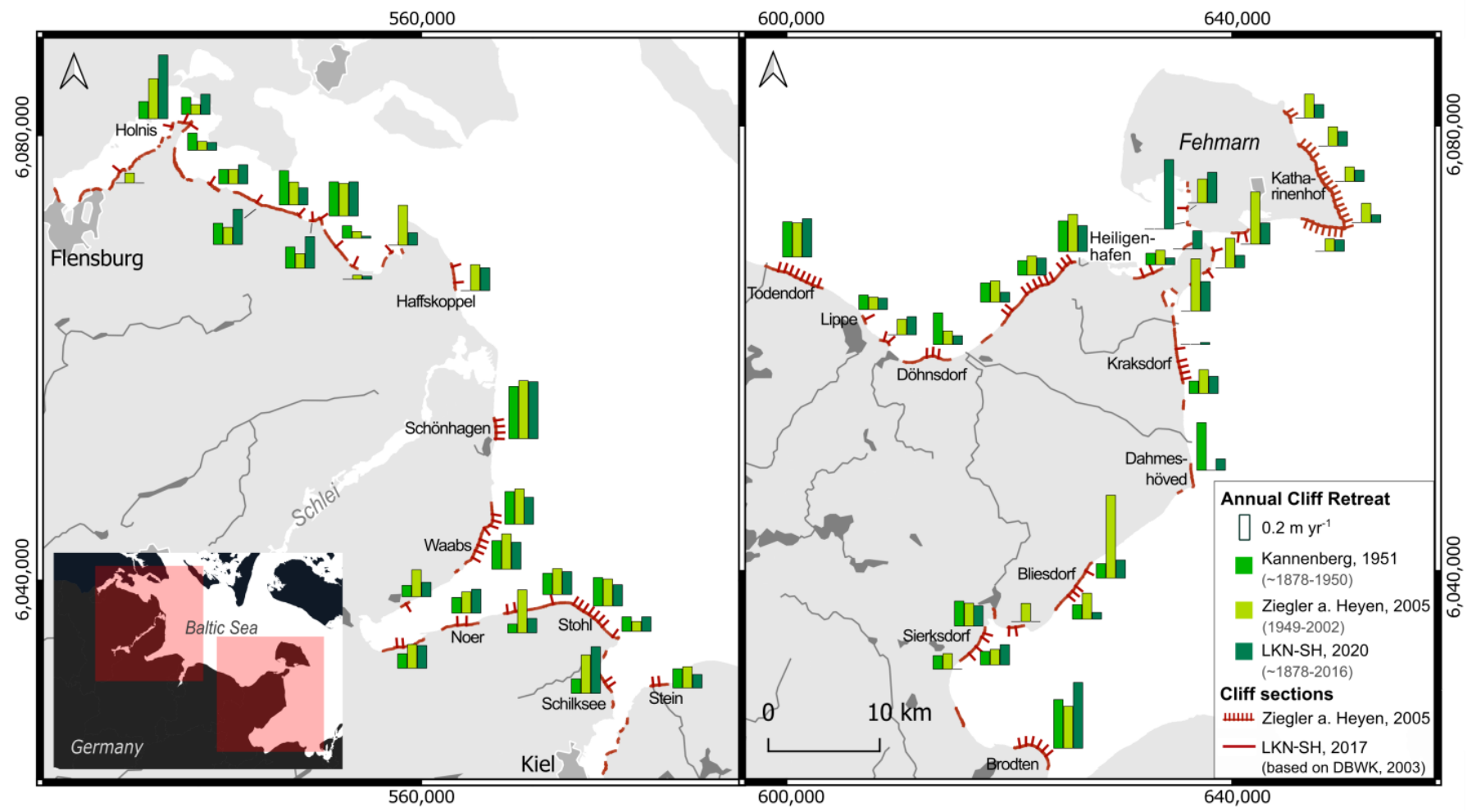

Figure 2. Annual cliff retreat $\left(\mathrm{m} \mathrm{yr}^{-1}\right)$ based on study results of Kannenberg [8], Ziegler and Heyen [36], and unpublished data from LKN-SH [52]. Detailed values in Table A1.

The investigations of Kannenberg [8] present the annual rates of cliff retreat of $<0.1-0.46 \mathrm{~m} \mathrm{yr}^{-1}$ and an overall weighted average of $\sim 0.22 \mathrm{~m} \mathrm{yr}^{-1}$ for the observed 73-years interval. In the study of Ziegler and Heyen [36], a weighted average retreat of $0.24 \mathrm{~m} \mathrm{yr}^{-1}$ was estimated ranging from $<0.1$ to $0.73 \mathrm{~m} \mathrm{yr}^{-1}$ at the individual cliffs for an average interval of 26 years (max. 44 years) between the surveys compared. The comparison of the cliff status between 1878 and 2016 shows the long-term retreat of $\sim 138$ years along the entire coastline. Here, the weighted average rate of cliff retreat is $\sim 0.19 \mathrm{~m} \mathrm{yr}^{-1}$, ranging from $<0.1$ to $0.64 \mathrm{~m} \mathrm{yr}^{-1}$ [52].

The rates of retreat differ between the different studies and locations (Figure 2, Table A1). While the annual retreat in the areas like Schönhagen $\left(0.46-0.51 \mathrm{~m} \mathrm{yr}^{-1}\right)$, Stohl (0.19-0.24 $\left.\mathrm{m} \mathrm{yr}^{-1}\right)$, and Heiligenhafen (0.23-0.33 $\left.\mathrm{m} \mathrm{yr}^{-1}\right)$ shows similar values in all three studies, greater differences occur in areas such as Schilksee and Bliesdorf (north). Here, the provided values for coastal retreat vary from 0.13 to $0.41 \mathrm{~m} \mathrm{yr}^{-1}$ and from 0.13 to $0.73 \mathrm{~m} \mathrm{yr}^{-1}$, respectively. However, the overall average cliff retreat for the Baltic Sea coast appears similar in all observations, with a range of $0.19-0.24 \mathrm{~m} \mathrm{yr}^{-1}$ (Table 1). 
Table 1. Length $\mathrm{L}(\mathrm{m})$ and yearly retreat rates $\mathrm{r}\left(\mathrm{m} \mathrm{yr}^{-1}\right)$ for the selected cliff sections and compiled for all active S-H cliffs (all local values shown in Table A1).

\begin{tabular}{|c|c|c|c|c|c|c|}
\hline \multirow[t]{2}{*}{ Location } & \multicolumn{2}{|c|}{$\begin{array}{l}\text { Kannenberg, } 1951 \\
\quad(\sim 1878-1950)\end{array}$} & \multicolumn{2}{|c|}{$\begin{array}{l}\text { Ziegler \& Heyen, } 2005 \\
(\sim 1949-2002)\end{array}$} & \multicolumn{2}{|c|}{$\begin{array}{c}\text { LKN-SH } \\
(\sim 1878-2016)\end{array}$} \\
\hline & $\mathrm{L}(\mathrm{m})$ & $r\left(m y^{-1}\right)$ & $\mathbf{L}(\mathrm{m})$ & $r\left(m y^{-1}\right)$ & $\mathrm{L}(\mathrm{m})$ & $r\left(\mathrm{~m} \mathrm{yr}^{-1}\right)$ \\
\hline 82.09 Schönhagen & 1600 & 0.46 & 1880 & 0.51 & 1570 & 0.50 \\
\hline 83.08 Stohl & 3000 & 0.25 & 3640 & 0.24 & 3880 & 0.19 \\
\hline 84.05 Schilksee & 1000 & 0.13 & 1140 & 0.34 & 1139 & 0.41 \\
\hline 85.12 Heiligenhafen & 1500 & 0.27 & 1560 & 0.33 & 2220 & 0.23 \\
\hline 86.21 Bliesdorf (north) & No data & 0.13 & 460 & 0.73 & 1270 & 0.16 \\
\hline All Cliffs S-H & 47,400 & 0.22 & 57,000 & 0.24 & 85,000 & 0.19 \\
\hline
\end{tabular}

\subsection{Erosional and Bulk Volume}

The volume of sediments eroding during the process of cliff retreat was determined for 50 cliff sections, in total spanning $\sim 57 \mathrm{~km}$ [36]. The results provide values for the specific volume ve-the annual material loss at the outcrop per meter-and the resulting specific bulk volume vb,1.75 (Figure 3; Table A2). In the studied area, the minimum value of $\mathrm{v}_{\mathrm{e}}$ is $0.3 \mathrm{~m}^{3} \mathrm{yr}^{-1} \mathrm{~m}^{-1}$ (85.06 Lippe), and the maximum value is $7.4 \mathrm{~m}^{3} \mathrm{yr}^{-1} \mathrm{~m}^{-1}$ (86.21 Bliesdorf (north)). A weighted average for the whole area-considering the local cliff lengths-amounts to about $\sim 2 \mathrm{~m}^{3} \mathrm{yr}^{-1} \mathrm{~m}^{-1}$. The absolute erosional volume from all the observed cliff sites $\mathrm{V}_{\mathrm{e}, \text { total }}$ amounts to $\sim 135,000 \mathrm{~m}^{3} \mathrm{yr}^{-1}$. The corresponding weighted average ( $\mathrm{min} / \mathrm{max}$ ) of vb,1.75 is $\sim 3.5 \mathrm{~m}^{3} \mathrm{yr}^{-1} \mathrm{~m}^{-1}\left(0.5 / 12.9 \mathrm{~m}^{3} \mathrm{yr}^{-1} \mathrm{~m}^{-1}\right)$ and the absolute volume of $\mathrm{V}_{\mathrm{b}, \text { total }}$ is $\sim 237,000 \mathrm{~m}^{3} \mathrm{yr}^{-1}$.

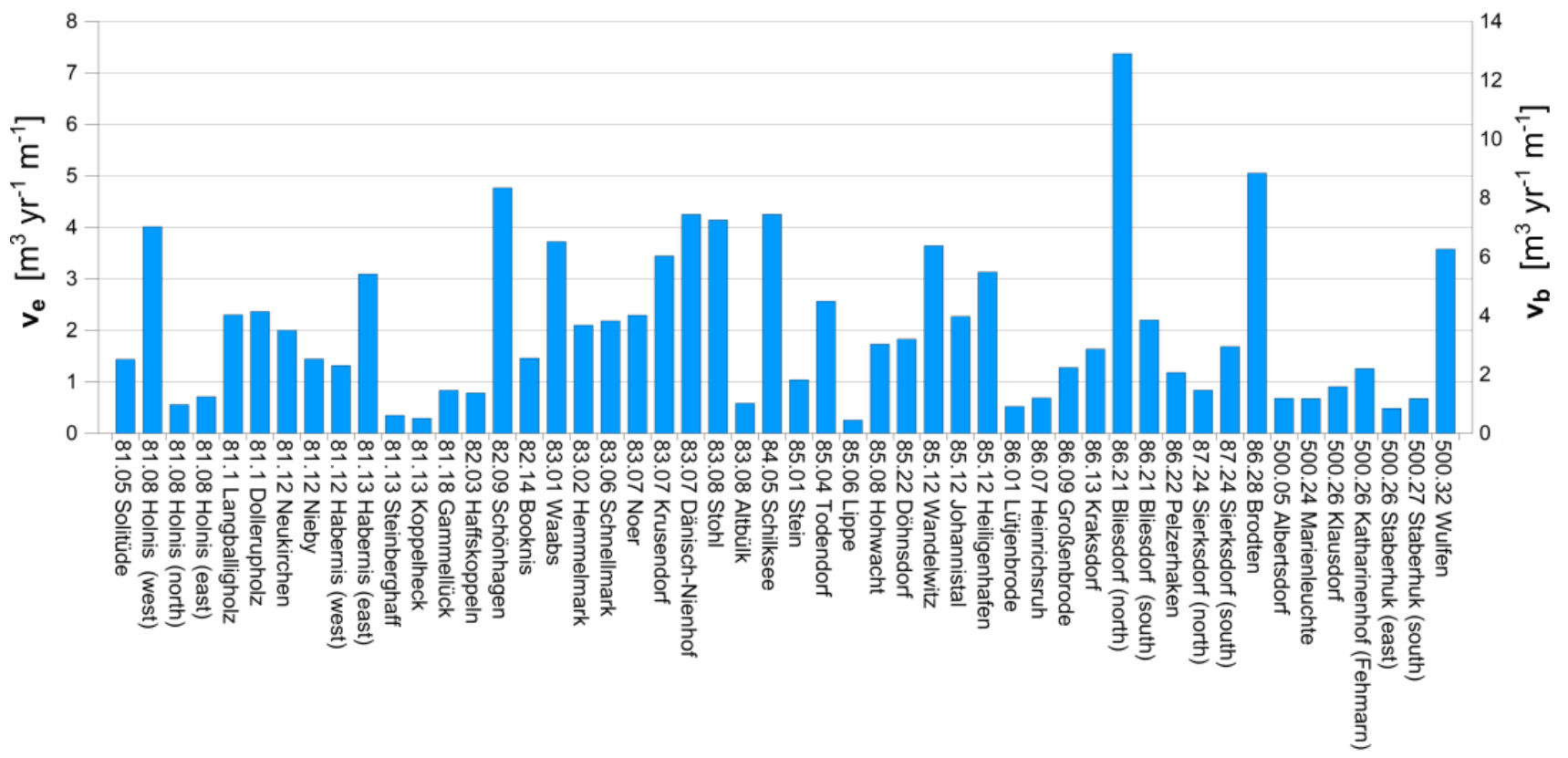

Figure 3. Specific eroded volumes $v_{e}$ (left axis) and specific bulk volumes vb (bulk factor h1.75) (right axis) of the observed 50 cliff sites, based on [36].

\subsection{Sediment Budget}

To calculate the littoral sediment budget vs per meter active cliff, site-specific values for the carbonate content $\mathrm{c}$ and the grain size fraction $\mathrm{n}(0.063-64 \mathrm{~mm})$ were applied if available in the reviewed literature: For $37(\sim 51 \mathrm{~km})$ of the 50 locations $(\sim 57 \mathrm{~km})$, a local carbonate value $\mathrm{c}$ is given, only for eight cliff sections $(\sim 15 \mathrm{~km})$ local values of $\mathrm{n}$ could be determined (Table A2). For these eight locations, a specific local sediment budget vs was calculated (Equation (4)). 
The values of vs range from a minimum of $0.2 \mathrm{~m}^{3} \mathrm{yr}^{-1} \mathrm{~m}^{-1}$ (86.09 Großenbrode) to a maximum of $5.5 \mathrm{~m}^{3} \mathrm{yr}^{-1} \mathrm{~m}^{-1}$ (86.28 Brodten) within the eight shown cliff sites (Figure 4). The values amount to $12-109 \%$ of the initially eroded volume $v_{e}$ and $7-62 \%$ of the bulk volume $\mathrm{vb}$ at the individual locations.

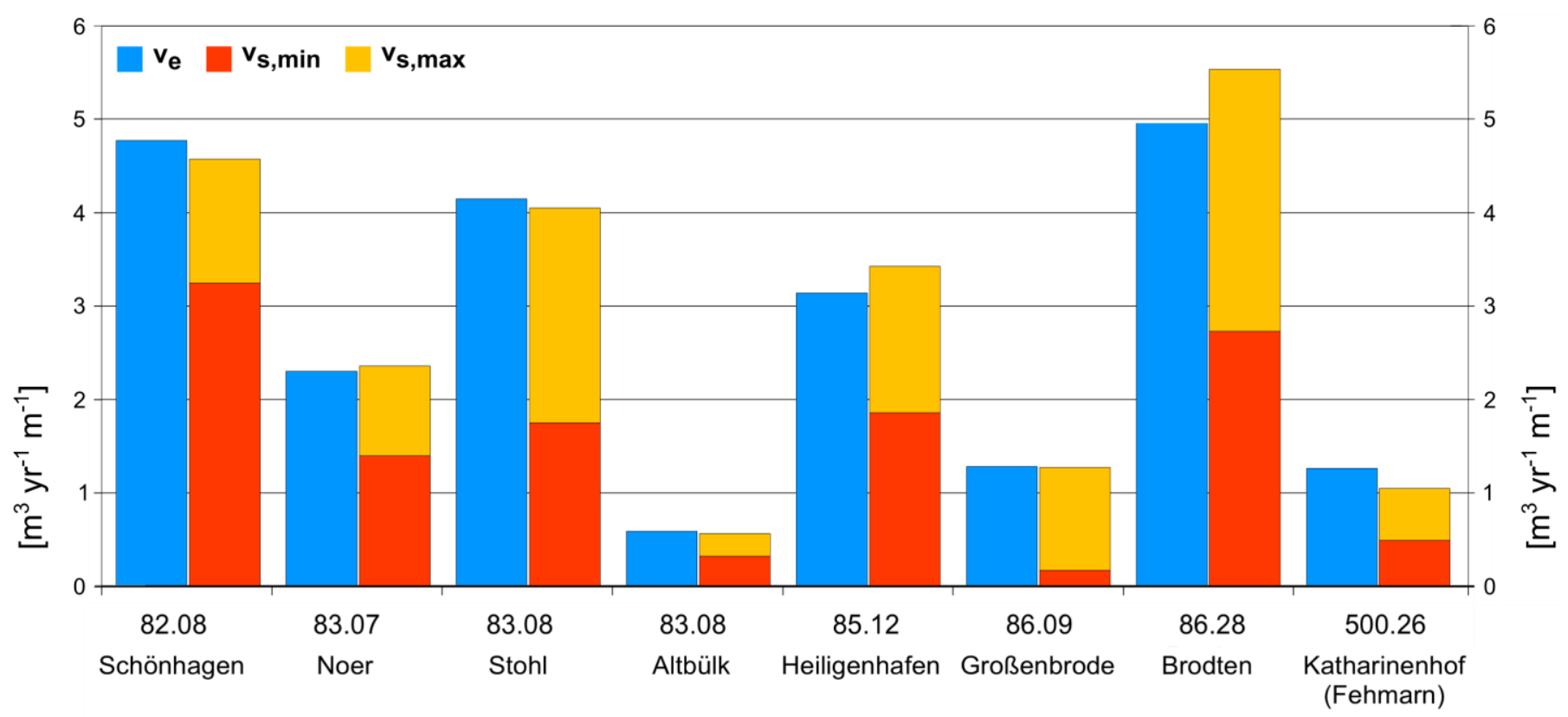

Figure 4. Specific erosional volume $\mathrm{v}_{\mathrm{e}}$ (blue) based on cliff retreat [36] and the calculated sediment budget range, $\mathrm{v}_{\mathrm{s}, \text { min }}$ (orange) to $\mathrm{v}_{\mathrm{s}, \max }$ (yellow), for the eight well-studied cliff locations. For specific values see Table A2.

Minimum and maximum estimates for the variables $\mathrm{c}$ and $\mathrm{n}$ were derived from local studies to describe the properties of the cliff-building material in the entire area (Table 2). They are in a range of $2.7-27 \%$ for the carbonate content $c$ and of $11-70 \%$ for the sediment fraction n (0.063-64 mm). No data are available on the amount of material $>64 \mathrm{~mm}$ (cobbles, boulders), which therefore must be neglected.

Table 2. Minima and maxima portions of $\mathrm{c}$ and $\mathrm{n}(0.063-64 \mathrm{~mm})$ in the cliff-building glacial till derived from local studies *. The sediment is classified according to Wentworth [53].

\begin{tabular}{ccc} 
& Glacial till Components & $\begin{array}{c}\text { Estimated Value Range } \\
\mathbf{( \% )}\end{array}$ \\
\hline $\mathrm{c}$ & Carbonate & $2.7-27$ \\
\hline \multirow{2}{*}{$\mathrm{n}$} & Sand $(0.063-2 \mathrm{~mm})$ & $11-61$ \\
& Granules, Pebbles $(2-64 \mathrm{~mm})$ & $0-9$ \\
${ }^{*}[8,23,31,39-41,43,46,47,54-58]$. & Cobbles, boulders $(>64 \mathrm{~mm})$ & No data \\
\hline
\end{tabular}

The derived estimates of $\mathrm{c}$ and $\mathrm{n}$ (Table 2) were applied to determine the littoral sediment budget for the remaining 42 locations $(\sim 42 \mathrm{~km})$ with insufficient local information (Figure 5). Compiling all results, we obtain a range of $<0.1-9.5 \mathrm{~m}^{3} \mathrm{yr}^{-1} \mathrm{~m}^{-1}$ for vs with a weighted average of $1.5 \mathrm{~m}^{3} \mathrm{yr}^{-1} \mathrm{~m}^{-1}$. This implies an absolute range of $39,000-161,000 \mathrm{~m}^{3} \mathrm{yr}^{-1}$ for the littoral sediment budget $\mathrm{V}_{\mathrm{s}, \text { total }}$ of the whole S-H coastline. It corresponds to $29-119 \%$ of the absolute erosional volume $V_{e, t o t a l}$ and $19-60 \%$ of the bulk volume $\mathrm{V}_{\mathrm{b} \text {,total }}$ of the area. 

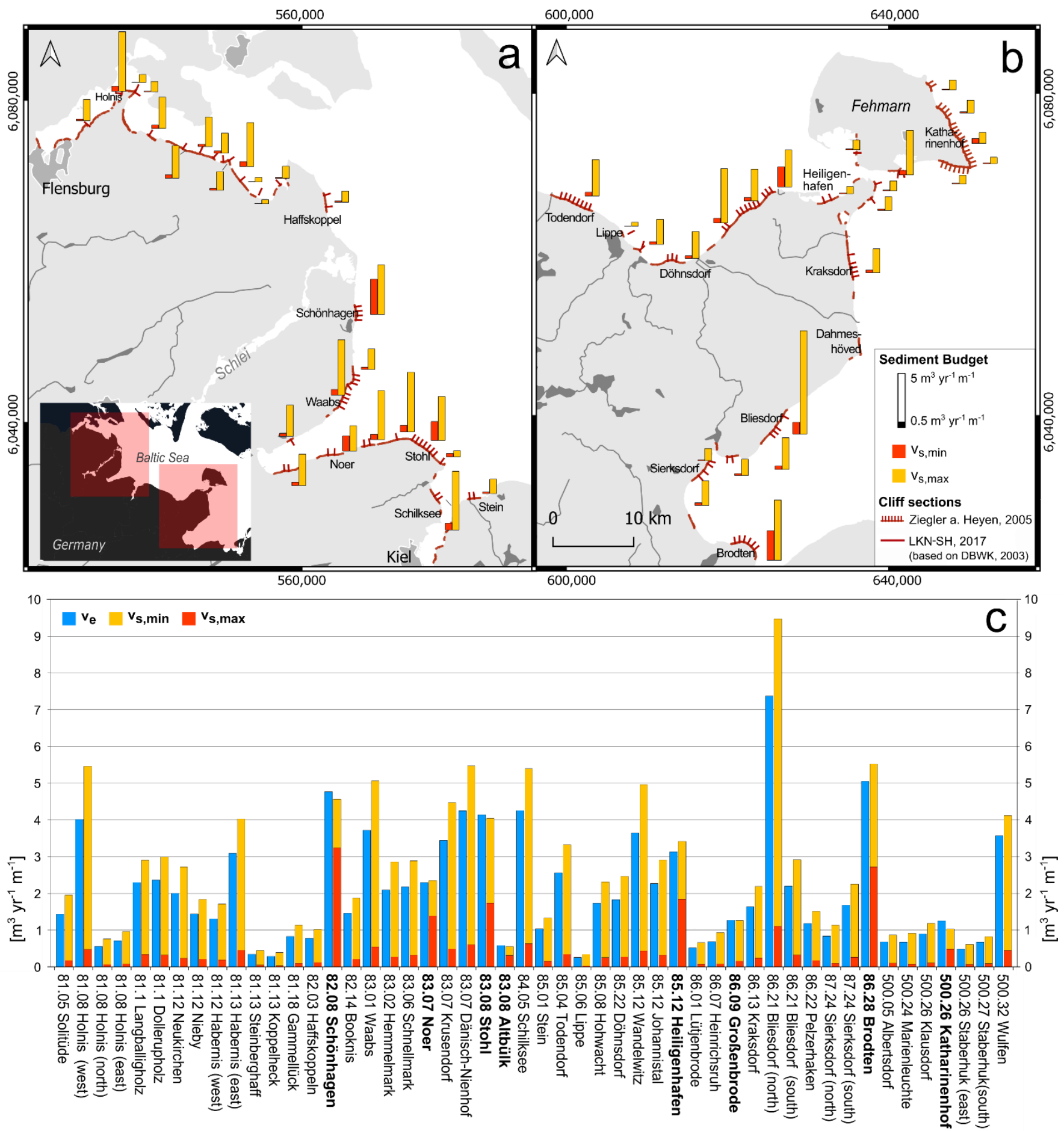

Figure 5. (a,b) Maps showing the calculated littoral sediment budget, $\mathrm{v}_{\mathrm{s}, \min }$ (orange) to $\mathrm{v}_{\mathrm{s}, \max }$ (yellow), for the local cliff sections; (c) comparison of the specific values of the erosional volume $\mathrm{v}_{\mathrm{e}}$ (blue) [36] and the littoral sediment budget $\mathrm{v}_{\mathrm{s}, \mathrm{min}}$ (orange) to $\mathrm{v}_{\mathrm{s}, \max }$ (yellow). Bold labels represent results based on available local data (Figure 4); all other results are based on derived estimates (Table 2).

\section{Discussion}

\subsection{Data Availability}

The present study builds on existing data from the literature. The results reflect the availability, characteristics, and quality of the data basis. The compilation of regional and local studies shows that the status of geoscientific research along the coastline is very 
diverse. Some areas have been the subject of extensive fundamental research due to, e.g., their geological specifications, their representative value for the regional coast, and/or their high political interest. These areas show good data coverage, e.g., Schönhagen (82.09), Heiligenhafen (85.12), and Brodten (86.28). In contrast, many other cliff sections, especially subsections in Flensburg Inner and Outer Fjord, in Lübeck Bay, and on Fehmarn Island, have barely been studied yet. Here, the literature does not contribute profitable information for our approach.

Thus, for the assessment of the littoral sediment budget (Equation (4)), we used the available data of well-studied locations to derive the minimum and maximum estimates for the input parameters of the entire area (Table 2). This takes into account the potential heterogeneity of the material but leads to the wide value range of the resulting budget volume. Intensifying the in situ operations at the poorly studied cliffs regarding local geology and sedimentology could decrease the factor of uncertainty of the input data and narrow down the resulting budget interval.

\subsection{Reliability of Data and Methods}

A high variety of interacting factors and processes influence the character and amount of the littoral sediment budget in the study area (Figure 6) [9,59].

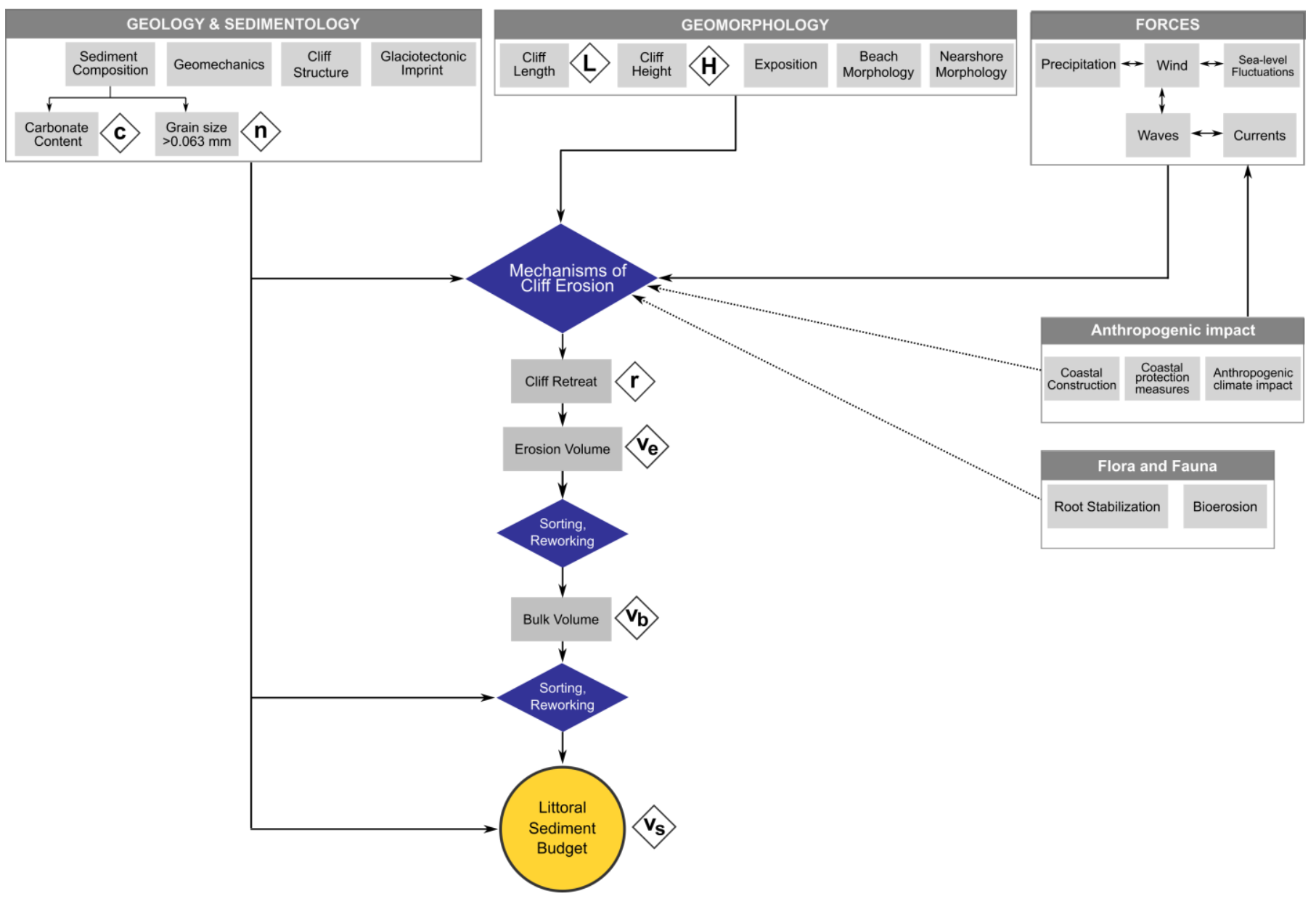

Figure 6. Factors and variables generating and/or affecting the littoral sediment budget from cliff erosion in a wavedominated environment.

Many of the involved factors, such as the cliff and beach morphology or the hydrodynamic forcing, do not specifically occur in the applied Equations ((1)-(4)). However, they are credited with an effect on the littoral sediment budget and are indirectly included in the calculation. So does the variable $v_{e}$ by definition (Equations (1) and (2)) include the 
rate of retreat $r$, which itself is controlled by, i.a., the sedimentological cliff properties, the nearshore morphology, and the intensity of the hydrodynamic forces $[12,36,60]$.

With ongoing observations and an evolving understanding of the system complexity, even more factors may need consideration, such as the influence of vegetation on the cliff stability and the anthropogenic activity $[11,59,61]$. While the introduction of new parameters can improve the study's reliability, at the same time it increases the complexity of the calculation and, thus, may enhance the number of measurement inaccuracies. This indicates an enhanced demand for scientific research on the effect of all considered factors and mutual dependencies in the system.

The following factors occur directly in this study's methodology (Equations (1)-(4)) as specific variables: the rate of cliff retreat $r$, the eroded volume ve, the bulk factor $h$, the carbonate content $\mathrm{c}$, and the grain size fraction $\mathrm{n}(0.063-64 \mathrm{~mm})$. The nature and conditions of these input data account for uncertainties of different kinds and dimensions in the results. Their cause and significance for the final sediment budget assessment as well as proposals to reduce these uncertainties are discussed in the following paragraphs.

\subsubsection{Rate of Cliff Retreat $r$}

The various results on cliff retreat presented in this study refer to different data bases (Figure 2; Table A1). These data bases may inherit positional inaccuracies due to their methods of measurement or interpretation. Visual evaluation of the Preußische Landesaufnahme ( 1878) revealed potential spatial inaccuracies up to $\pm 25 \mathrm{~m}$ in reference to the DBWK [62]. For the resulting annual rate of retreat, this would apply an uncertainty of $\pm 0.18 \mathrm{~m} \mathrm{yr}^{-1}$ considering an average retreat of $0.19 \mathrm{~m} \mathrm{yr}^{-1}$ for a period of $\sim 138$ years [52]. The long period can partly compensate for the high spatial inaccuracies. Still, the uncertainty is almost as high as the actual retreat rate and, hence, of little informative value. Spatial evaluations of the compiled surveys used by Ziegler and Heyen [36] indicate relatively small inaccuracies of $\pm 0.15 \mathrm{~m}$, which propose a small error of about $\pm 0.005 \mathrm{~m} \mathrm{yr}^{-1}$ with respect to the average retreat of $0.24 \mathrm{~m} \mathrm{yr}^{-1}$ for an average period of $\sim 26$ years. Despite the smaller uncertainty, we cannot verify the higher reliability of the data in reference to the DBWK.

In general, the comparability between the different study results is limited by the varying observed time intervals and the mechanisms of cliff erosion, as single erosion events highly affect the short-term and local retreat velocity [11,17]. We assume that the different rates of retreat (Figure 2) do not necessarily represent a change in the retreat behavior over time but instead represent the discrepancies within the data bases. For a reliable approximation of $\mathrm{r}$, a compromise must be worked out between the long measuring periods and data accuracy.

\subsubsection{Volume Erosion ve}

The budget assessment in this study is based on the erosional volumes $V_{\mathrm{e}}$ determined from $L, H$, and $r$ [36] (Equation (1)). Other studies [8,52] that show deviating values for the input parameters $\mathrm{L}$ and $\mathrm{r}$ (Figure 2; Table 1) would produce differing values of Ve. While the deviations of $r$ are explained above (5.2.1), further deviations can be triggered by the following:

(a) The definitions of the active cliff sections, on which the retreat analyses are based, are not equal. Ziegler and Heyen [36] included the cliff sections with a minimum height of $2 \mathrm{~m}$ and a minimum length of $50 \mathrm{~m}$ in their investigations referring to a coastal survey from $\sim 1974$ by the former Landesamt für Wasserhaushalt und Küsten (LW). More recent analyses from LKN-SH use the cliff definition by the Schleswig-Holstein state ordinance on legally protected biotopes, which states a minimum of $1.2 \mathrm{~m}$ in height and $25 \mathrm{~m}$ in length [63]. Additionally, the status of activity, based on DBWK (2003) [35,37], has not been applied in the study of [36]. The comparison proposes an underestimation of the active cliff length $L$ applied in this study [36]. 
(b) The retreat analysis of [36] is based on the cliff status from $\sim 1974$. The status of the cliffs-active or inactive-could have changed with time, e.g., due to a natural intensification or a decrease in the local hydrodynamic impact or the installation of coastal protection measures $[25,26]$.

For a major improvement of the accuracy and validity of this study's results, we suggest a recalculation of $\mathrm{V}_{\mathrm{e}}$ based on an updated and reviewed definition of the active cliff length and the best possible approximation of the retreat rate $r$ considering the current data [52] and future measurements.

\subsubsection{Bulk Volume vb}

During cliff erosion, when the material breaks or slumps down, the structure is loosened, the density decreases, and hence the material volume increases. The extent of this volume expansion depends on the material properties and the degree of consolidation in its initial state-here represented by the bulk factor $\mathrm{h}[13,20]$ (Equation (3)). For the cohesive cliff sediments in the area, a bulk factor h of 1.5-2 was proposed [20]. We assume that neither the vertical nor the horizontal heterogeneity of the material properties at the cliffs are sufficiently represented by the variable h. However, due to a lack of local information regarding the dry bulk density and the grain size distribution, this is the best available approximation for $\mathrm{h}$ in the studied area.

Certainly, local investigations of the cliff's geomechanical properties and bulk experiments could help to define an individual bulk factor $\mathrm{h}$ for each cliff section, which would more accurately represent the material properties and may decrease the uncertainties contained in the variable $h$.

\subsubsection{Carbonate Content c}

Due to the atmospheric and marine influence on the outcrop, the carbonate content of the exposed cliff material can be strongly reduced over time. Along the cliff face, rainwater and surface runoff intrude into cracks and fissures and initiate chemical weathering [22,23]. With the start of a marine hydrodynamic impact, physical erosion, sorting, and transport processes are initiated. The fine carbonate particles are removed within suspension, such as the fine siliciclastic particles. Hence, we assume a full removal of the contained carbonate $c$ for the assessment of the littoral sediment volume (Equation (4)). From local analyses of the cliff matrix, values between 2.7\% (83.01 Waabs) and 27\% (500.26 Klausdorf, Fehmarn) were identified for c. However, according to Glückert [23], in most cliff samples, the carbonate content is in a narrower range of $6-17 \%$, whereas local accumulations contain up to $60 \%$ carbonate (e.g., chalk marl at Brodten (86.28)) [23,40]. This heterogeneity makes it difficult to apply representative values for $\mathrm{c}$ to the budget calculations.

The influence of precipitation on the carbonate-rich cliff material can also lead to cementing of siliciclastic sediment grains due to alternating reprecipitation and drying [22]. This may lead to a shift of the grain size modus towards larger particles and, thus, potentially to an overestimation of the littoral sediment budget. It remains unclear if and how fast the cemented carbonate particles are removed from the sediment under the prevalent environmental conditions and hence if the carbonate still plays a role in the initiated phases of sediment transport and deposition.

To narrow down the uncertainties of factor $c$ in the budget calculation, dedicated quantitative sediment analyses are necessary at the cliff sites that (a) provide the amount of carbonate at local sites that have not yet been investigated and (b) demonstrate the evolution of carbonate removal during the process of sediment mobilization from the cliff source towards the nearshore areas.

\subsubsection{Sediment Fraction $n$}

In this study, the sediment fraction $\mathrm{n}(0.063-64 \mathrm{~mm})$ represents the proportion of siliciclastic particles that enters the marine environment and contributes to the littoral sediment transport and coastal accumulation. However, parts of the sand fraction with 
grain sizes $<0.2 \mathrm{~mm}$ can be transported further offshore by strong current and wave action and, thus, be removed from the littoral system $[27,64,65]$. Thereby, the lower grain size limit of the sediment that remains in the nearshore area is not temporally and spatially consistent. It rather depends on the interplay between the hydrodynamic forcing and local morphology, and the general availability of sediments $[21,65,66]$. For a differentiated analysis of the sandy sediment according to their mobility behavior, we require further knowledge of the local dynamics and detailed quantitative information about sedimentary sub-fractions, which is not provided bymost local studies in S-H.

In this approach, we considered the whole sand fraction as part of the littoral sediment budget vs, which may lead to an overestimation of the budget volume by the varying amount of the fine-grained particles $(0.063-0.2 \mathrm{~mm})$. At the same time, there is the risk of an underestimation of the budget volume by the coarser sediment fraction: Besides the sandy sediments, larger stones and boulders are mobilized from the Pleistocene cliff deposits and contribute to the beach and nearshore sediment [11,24]. Due to issues of sample representativity and difficulties in the analyses of the coarse grain size fractions [67], the literature lacks quantitative data of those fractions. The number of granules and pebbles $(2-64 \mathrm{~mm})$ could only be included in the budget calculation in very few cases, e.g., from studies of $[8,47,54,57]$. For grain sizes $>64 \mathrm{~mm}$ (cobbles, boulders), no quantitative data were available. Although stones and boulders have been proven to be partly mobile in the nearshore system $[11,24]$, they are underrepresented in this study's budget estimation.

For the actual budget calculation, only from eight $(\sim 15 \mathrm{~km})$ of the observed $50(\sim 57 \mathrm{~km})$ cliff locations detailed grain size information is available (Figure 4). For all other locations, we applied the minimum and maximum estimates shown in Table 2 and assumed that the cliffs are built exclusively of glacial till with homogeneous geological properties. This is a strong simplification of the prevailing situation. Sediment samples of different locations show that the grain size distribution of the cliff-building material is highly variable on a small spatial scale due to their geological genesis [39,56]. Thus, all local budget calculations, based on available local data or derived estimates, hold a certain degree of uncertainty and cannot fully represent the highly heterogenous cliff geology.

To decrease this degree of uncertainty, we need to expand the geological and sedimentological investigations of the local cliff areas. It is crucial to access the uncategorized grain size data for differentiated analyses of the sediment availability and mobility. Moreover, investigations on coarse-grained material have to be enhanced, e.g., by using digital image analyses.

\subsection{Comparison and Evaluation of the Littoral Sediment Budget}

This study is the first assessment of the material contribution from cliff retreat to the littoral sediment budget for the entire Baltic Sea coastline of S-H. To evaluate the result, we may compare it to areas with similar regional conditions and consider other potential material sources.

\subsubsection{National and International Comparison}

Eastward of our study area extends the German Baltic Sea coastline of MecklenburgVorpommern (M-V). Similar to S-H, the coastal appearance is characterized by alternating cliffs and lowlands and is constantly modified by marine forces and dynamic processes [68]. We expect a larger material erosion $\mathrm{v}_{\mathrm{e}}$ from the cliffs of $\mathrm{M}-\mathrm{V}$ compared to $\mathrm{S}-\mathrm{H}$ due to the prevailing circumstances:

1. The length of the currently active, unprotected cliffs in $M-V$ is $\sim 125 \mathrm{~km}$-about $40 \mathrm{~km}$ longer than in S-H ( 85 km; Schlei excluded) $[68,69]$.

2. The proposed average annual cliff retreat in $\mathrm{M}-\mathrm{V}$ is $\sim 0.34 \mathrm{~m} \mathrm{yr}^{-1}$ [70]—slightly higher than in S-H $\left(\sim 0.19-0.24 \mathrm{~m} \mathrm{yr}^{-1}\right)$.

3. The $\mathrm{M}-\mathrm{V}$ cliffs are higher on average. Some of them reach up to $\sim 120 \mathrm{~m}$ high, e.g., the Jasmund cliff on Rügen Island. 
The average proposed $\mathrm{v}_{\mathrm{e}}$ for the whole $\mathrm{M}-\mathrm{V}$ coast is $\sim 7 \mathrm{~m}^{3} \mathrm{yr}^{-1} \mathrm{~m}^{-1}$. The highest material input of $30 \mathrm{~m}^{3} \mathrm{yr}^{-1} \mathrm{~m}^{-1}$ is observed at the cliffs of Sellin (Rügen Island) and Streckelsberg (Usedom Island) [71]. Looking even further eastward to the adjoining coastline of western Poland, case studies report a volume erosion $\mathrm{v}_{\mathrm{e}}>5.5 \mathrm{~m}^{3} \mathrm{yr}^{-1} \mathrm{~m}^{-1}$ for the cliff sections of Wolin Island (Pomeranian Bay) [72,73].

For comparison, the average $\mathrm{v}_{\mathrm{e}}$ in S-H is only $2 \mathrm{~m}^{3} \mathrm{yr}^{-1} \mathrm{~m}^{-1}$, with a maximum of $7.4 \mathrm{~m}^{3} \mathrm{yr}^{-1} \mathrm{~m}^{-1}$ (Bliesdorf (north)). Only from $1 \%$ of the active cliffs $\mathrm{v}_{\mathrm{e}}>5.5 \mathrm{~m}^{3} \mathrm{yr}^{-1} \mathrm{~m}^{-1}$ is expected (Table A2). Thus, a relatively low amount of sediments is provided from the $\mathrm{S}-\mathrm{H}$ cliffs compared to the adjacent areas.

However, for a valid comparison, the cliffs have to be distinguished according to their geological and sedimentological properties. Besides the cohesive cliff deposits, made up mainly of glacial till, glaciofluvial, and glaciolimnic sediments, Cretaceous hard-rock cliffs are present in the eastern part of M-V (Jasmund, Rügen Island), which vary in their retreat behavior under hydrodynamic impact. They deliver mostly calcareous material that does not contribute to the littoral sediment budget. Others of the M-V and Polish Baltic Sea cliffs are mainly build-up of interstadial basin sediments, mostly glaciolimic silts and fine sands [71]. These sediments also play a minor role in the littoral sediment budget.

It becomes apparent that not only in S-H but also in the adjacent coastal areas the sediment supply by cliffs is limited and thus most of the beaches and nearshore bar systems constantly suffer from a deficit in coast-stabilizing sediment. For the protection of the current coastline, beach nourishment is crucial. In $\mathrm{M}-\mathrm{V}$, sand has been procured from offshore deposits since 1968 [71]. S-H lacks such deposits. Hence, sand nourishment is a significantly less frequent coastal protection measure in S-H. It is mostly performed for economic reasons with imported resources and high financial expenses [74].

The erosion of cohesive shorelines also occurs in other areas of the mid- to high latitudes, e.g., in parts of the English and Irish coast $[18,29]$ as well as in North America and Canada $[75,76]$.

At the lower Great Lakes, for example, about $40 \%$ of the shoreline is characterized by 2-30 m-high cliffs. They consist of glacial, glaciofluvial, and glaciolimnic sediments and are bordered by narrow beaches. Retreat rates are comparatively high: they exceed $0.5 \mathrm{~m} \mathrm{yr}^{-1}$ in most areas and locally reach values $>1.5 \mathrm{~m} \mathrm{yr}^{-1}$ [77]. Similar to the S-H coastline, high temporal and spatial variation occurs. Due to comparable characteristics regarding morphology, geology, and retreat, we expect similar mechanisms of erosion, sorting, and transport with the impact of hydrodynamic forces to the S-H Baltic Sea coastline. Case studies at individual lake sections provide further information about the availability of sediments from cliff retreat. Here, per meter cliff, an input of sand and gravel (vs) of 1.6-8.2 $\mathrm{m}^{3} \mathrm{yr}^{-1} \mathrm{~m}^{-1}$ was calculated [78], which presents a comparable value range to the littoral sediment budget in S-H of $<0.1-9.5 \mathrm{~m}^{3} \mathrm{yr}^{-1} \mathrm{~m}^{-1}$. We assume that the Great Lakes represent a potential comparison area to $\mathrm{S}-\mathrm{H}$ to perform further research on the complex system interplay and evaluate the role of the littoral sediment budget supplied by cohesive cliff deposits.

\subsubsection{Comparison of Sediment Sources: Seafloor Abrasion}

To assess the role of the active cliffs as a sediment source for the coastal zones, we consult other potential source areas. Besides the cohesive cliff deposits, other suppliers of littoral sediments are rivers and submarine abrasion platforms [3,79]. In the study area, the river discharge can be neglected as a material source [27], whereas the abrasion platforms are highly relevant [80]. Here, the Pleistocene hard substrate, glacial till, of the seafloor is eroded mostly due to wave action $[11,39,79]$. The mobilized material accounts for a considerable amount of sediment that enters the coastal system $[7,11]$. Case studies propose that the abrasion platforms in front of active cliffs may supply more than $80 \%$ of the absolute local material input $[27,80]$ and, thus, may constitute an even more valuable sediment source than the terrestrial cliffs [81]. However, for a reliable quantitative assessment of the sediment provided from seafloor abrasion, more research is required regarding, e.g., the 
geomechanical properties, the mineralogical and sedimentological composition of the hard substrate, as well as the influence of biological activity, e.g., boring organisms $[80,82,83]$. Additionally, the local intensity and the seaward delimitation of the abrasive activity have to be determined. As they vary with, e.g., changing wave heights and water levels, this is difficult to implement $[11,84]$. Thus, the quantification of the littoral sediment supplied from the seafloor remains speculative due to limited knowledge and measuring techniques.

Besides the role as a highly relevant sediment source, the seafloor abrasion promotes the ongoing cliff recession [79]. It influences the nearshore morphology and, hence, the intensity of the hydrodynamic impact of the cliff $[11,79,80]$. This emphasizes again the need for research in the offshore areas.

\section{Conclusions}

In this study, we have compiled data from available literature and performed analyses regarding the active cliff sections of the sediment-starved German Baltic Sea coast of the state of Schleswig-Holstein, Germany. Based on the dynamic and static properties of these cliffs and their contribution to the littoral sediment availability-compiled in Tables A1 and A2-we draw the following conclusions:

1. The active cliffs present a major sediment source for the sediment-starved Baltic Sea coast of S-H. Due to ongoing cliff erosion, about 39,000-161,000 $\mathrm{m}^{3} \mathrm{yr}^{-1}$ of sediments $(0.063-64 \mathrm{~mm})$ are annually supplied to the nearshore system. This is essential for the coastal transport and the stabilization of adjacent sandy shorelines. As such, the active cliffs deliver an important ecosystem service for coastal protection.

2. Due to the complex interplay of cliff properties, forces, and processes, and the limited data availability, uncertainties remain with respect to the exact volumes of the littoral sediment budget. Although those cannot be quantified on the given data basis, we assume that the determined volume interval gives a fair indication of the dimension of the sediment budget.

3. For a comprehensive evaluation of the littoral sediment budget along the S-H coastline, the study has to be expanded offshore. Here, the erosion of the hard-bottom seafloor accounts for a considerable amount of sediment and, thus, adds another relevant sediment source to the system. The volumes of supplied material from abrasion platforms have not yet been reliably quantified.

The findings of this study indicate that further research is required to decrease uncertainties and improve the accuracy and reliability of the final result-the littoral sediment budget. Investigations shall aim towards an improved local knowledge of the heterogenous cliff properties and an enhanced understanding of the interplay of forces that control the local cliff retreat. Additionally, we aim to improve the data basis for investigations of cohesive cliff morphodynamics. However, the review of available studies and the implementation of older data remains inevitable to provide a well-founded assessment for the long-term development along the Baltic Sea coast of S-H and to derive future prospects.

Author Contributions: Conceptualization, T.A. and C.W.; formal analysis, T.A.; funding acquisition, J.L.A.H.; investigation, T.A.; methodology, T.A.; project administration, J.L.A.H., A.H., H.-C.R. and C.W.; resources, T.A., A.H., H.-C.R. and C.W.; supervision, C.W.; visualization, T.A.; writing-original draft, T.A.; writing-review and editing, T.A., J.L.A.H., A.H., H.-C.R. and C.W. All authors have read and agreed to the published version of the manuscript.

Funding: This research resulted from the project Sediment Budget Baltic Sea, a research cooperation between the Kiel University and the Schleswig-Holstein Ministry of Energy Transition, Agriculture, Environment, Nature and Digitization (MELUND), the Schleswig-Holstein State Office for Coastal Protection, National Park and Marine Protection (LKN-SH), and the State Agency for Agriculture, Environment and Rural Areas-Schleswig-Holstein (LLUR). The project was funded by the Schleswig-Holstein Ministry of Energy Transition, Agriculture, Environment, Nature and Digitization (MELUND). We acknowledge financial support by Land Schleswig-Holstein within the funding programme Open Access Publikationsfonds. 
Institutional Review Board Statement: Not applicable.

Informed Consent Statement: Not applicable.

Acknowledgments: We would like to greatly thank Klaus Schwarzer for sharing his broad expertise in the field of local geology, cliff retreat, and sediment dynamics in the studied area. We also want to acknowledge his initiation and heading of the project 'Sediment Budget Baltic Sea' and his constructive contribution during the project work and manuscript preparation. We also want to thank Kay Krienke (LLUR) for his participation in discussions regarding cliff geology. We thank the anonymous reviewers for their suggestions to improve the manuscript. Finally, we wish to thank Giuliana A. Diaz Mendoza, Gianna Persichini, Gitta A. von Rönn, and Joscha Loose for lively discussions and helpful and solution-oriented support in many aspects.

Conflicts of Interest: The authors declare no conflict of interest.

Appendix A

Table A1. Compilation of Cliff Retreat along the Baltic Sea coast of S-H, Germany, based on data from $[8,36,52]$.

\begin{tabular}{|c|c|c|c|c|c|c|c|c|c|}
\hline \multirow{2}{*}{ Section No. } & \multirow{2}{*}{ Location } & \multicolumn{3}{|c|}{$\begin{array}{l}\text { Kannenberg, } 1951 \\
\quad(\sim 1878-1950)\end{array}$} & \multicolumn{3}{|c|}{$\begin{array}{c}\text { Ziegler and Heyen, } 2005 \\
\text { (1949-2002) }\end{array}$} & \multicolumn{2}{|c|}{$\begin{array}{l}\text { LKN-SH } \\
(\sim 1878-2016)\end{array}$} \\
\hline & & & $\begin{array}{c}r \\
\left(\mathrm{~m} \mathrm{yr}^{-1}\right)\end{array}$ & $\begin{array}{c}\mathrm{L} \\
(\mathrm{m})\end{array}$ & $\begin{array}{c}r \\
\left(\mathrm{~m} \mathrm{yr}^{-1}\right)\end{array}$ & $\begin{array}{c}r_{\max } \\
\left(\mathrm{m} \mathrm{yr}^{-1}\right)\end{array}$ & $\begin{array}{c}\mathrm{L} \\
(\mathrm{m})\end{array}$ & $\begin{array}{c}r \\
\left(\mathrm{~m} \mathrm{yr}^{-1}\right)\end{array}$ & $\begin{array}{c}\mathrm{L} \\
(\mathrm{m})\end{array}$ \\
\hline 81.05 & Solitüde & & & & 0.09 & 0.12 & 110 & - & 105 \\
\hline 81.08 & Holnis (west) & \multirow{3}{*}{ Holnis } & \multirow{3}{*}{0.15} & \multirow{3}{*}{800} & 0.35 & 0.49 & 240 & 0.56 & 478 \\
\hline 81.08 & Holnis (north) & & & & 0.09 & 0.12 & 240 & 0.18 & 237 \\
\hline 81.08 & Holnis (east) & & & & 0.08 & 0.16 & 280 & 0.07 & 276 \\
\hline 81.1 & Langballiholz & Lanballigholz & - & 800 & 0.32 & 0.41 & 330 & 0.23 & 335 \\
\hline 81.1 & Dollerupholz & Dollerupholz & 0.13 & 2300 & 0.13 & 0.2 & 610 & 0.17 & 610 \\
\hline 81.12 & Neukirchen & \multirow{2}{*}{ Neukirchen } & \multirow{2}{*}{0.19} & \multirow{2}{*}{1000} & 0.15 & 0.21 & 310 & 0.31 & 311 \\
\hline 81.12 & Nieby & & & & 0.13 & 0.18 & 470 & 0.28 & 470 \\
\hline 81.12 & Habernis (west) & \multirow{2}{*}{ Habernis } & \multirow{2}{*}{0.30} & \multirow{2}{*}{800} & 0.2 & 0.26 & 340 & 0.15 & 338 \\
\hline 81.13 & Habernis (east) & & & & 0.29 & 0.93 & 590 & 0.30 & 591 \\
\hline 81.13 & Steinberghaff & Steinberghaff & 0.11 & 1200 & 0.06 & 0.09 & 870 & 0.02 & 747 \\
\hline 81.13 & Koppelheck & & - & - & 0.04 & 0.08 & 190 & 0.03 & 345 \\
\hline 81.18 & Gammellück & Geltinger Bucht & - & 1800 & 0.35 & 0.48 & 280 & 0.11 & 178 \\
\hline 82.03 & Haffskoppel & Düttebüll & - & 1000 & 0.23 & 0.18 & 840 & 0.20 & 1396 \\
\hline 82.08 & Schönhagen & Schönhagen & 0.46 & 1600 & 0.51 & 0.96 & 1880 & 0.50 & 1571 \\
\hline 82.14 & Booknis & Boknis & 0.29 & 1600 & 0.3 & 0.44 & 2010 & 0.24 & 2637 \\
\hline 83.01 & Waabs & Waabs & 0.25 & 2200 & 0.31 & 0.6 & 2140 & 0.24 & 2902 \\
\hline 83.02 & Hemmelmark & Hemmelmark & 0.10 & 400 & 0.24 & 0.38 & 640 & 0.13 & 754 \\
\hline 83.06 & Schnellmark & Altenhof & 0.13 & 1000 & 0.21 & 0.48 & 900 & 0.20 & 1553 \\
\hline 83.07 & Noer & Nör & 0.14 & 1500 & 0.19 & 0.26 & 1340 & 0.21 & 1334 \\
\hline 83.07 & Krusendorf & Surendorf & 0.08 & 800 & 0.38 & 0.53 & 750 & 0.13 & 1555 \\
\hline 83.07 & Dänisch-Nienhof & Dän. Nienhof & 0.19 & 1300 & 0.23 & 0.38 & 440 & 0.20 & 1096 \\
\hline 83.08 & Stohl & Stohl & 0.25 & 3000 & 0.24 & 0.68 & 3640 & 0.19 & 3884 \\
\hline 83.08 & Altbülk & Alt-Bülk & 0.13 & 300 & 0.09 & 0.15 & 310 & 0.13 & 796 \\
\hline 84.05 & Schilksee & Schilksee & 0.13 & 1000 & 0.34 & 0.56 & 1140 & 0.41 & 1139 \\
\hline 85.01 & Stein & Stein & 0.17 & 1200 & 0.19 & 0.39 & 1290 & 0.12 & 1510 \\
\hline 85.04 & Todendorf & Satjendorf & 0.31 & 3000 & 0.3 & 0.86 & 4120 & 0.34 & 5493 \\
\hline
\end{tabular}


Table A1. Cont.

\begin{tabular}{|c|c|c|c|c|c|c|c|c|c|}
\hline \multirow{2}{*}{ Section No. } & \multirow{2}{*}{ Location } & \multicolumn{3}{|c|}{$\begin{array}{l}\text { Kannenberg, } 1951 \\
\quad(\sim 1878-1950)\end{array}$} & \multicolumn{3}{|c|}{$\begin{array}{c}\text { Ziegler and Heyen, } 2005 \\
(1949-2002)\end{array}$} & \multicolumn{2}{|c|}{$\begin{array}{c}\text { LKN-SH } \\
(\sim 1878-2016)\end{array}$} \\
\hline & & & $\begin{array}{c}\mathrm{r} \\
\left(\mathrm{m} \mathrm{yr}^{-1}\right)\end{array}$ & $\begin{array}{c}\mathrm{L} \\
(\mathrm{m})\end{array}$ & $\begin{array}{c}\mathrm{r} \\
\left(\mathrm{m} \mathrm{yr}^{-1}\right)\end{array}$ & $\begin{array}{c}r_{\max } \\
\left(m \mathrm{yr}^{-1}\right)\end{array}$ & $\begin{array}{c}\mathrm{L} \\
(\mathrm{m})\end{array}$ & $\begin{array}{c}\mathrm{r} \\
\left(\mathrm{m} \mathrm{yr}^{-1}\right)\end{array}$ & $\begin{array}{c}\mathrm{L} \\
(\mathrm{m})\end{array}$ \\
\hline 85.06 & Lippe & Lippe & 0.13 & 200 & 0.11 & 0.15 & 180 & 0.10 & 680 \\
\hline 85.08 & Hohwacht & Hohwacht & - & 300 & 0.14 & 0.2 & 430 & 0.16 & 536 \\
\hline 85.22 & Döhnsdorf & Weißenhaus & 0.28 & 1200 & 0.12 & 0.26 & 1530 & 0.08 & 2196 \\
\hline 85.12 & Wandelwitz & Putlos & 0.17 & 2000 & 0.19 & 0.36 & 1080 & 0.09 & 3180 \\
\hline 85.12 & Johannistal & Johannistal & 0.13 & 1500 & 0.17 & 0.46 & 3080 & 0.15 & 3428 \\
\hline 85.12 & Heiligenhafen & Heiligenhafen & 0.27 & 1500 & 0.33 & 1.16 & 1560 & 0.23 & 2215 \\
\hline 86.01 & Lütjenbrode & Lütjenbrode & 0.10 & 2000 & 0.13 & 0.19 & 1370 & 0.06 & 2655 \\
\hline 86.05 & Fehmarnsund & & & & & & & 0.16 & 863 \\
\hline 86.07 & Heinrichsruh & & & & 0.26 & 0.49 & 550 & 0.11 & 1148 \\
\hline 86.09 & Großenbrode & Großenbrode & & 1000 & 0.46 & 0.69 & 710 & 0.26 & 721 \\
\hline 86.13 & Ölendorf & & & & & & & 0.02 & 758 \\
\hline 86.13 & Kraksdorf & Siggen & 0.11 & 3800 & 0.21 & 0.34 & 2980 & 0.15 & 4943 \\
\hline 86.15 & Rosenfelde & & & & & & & 0.00 & 705 \\
\hline 86.17 & Dahmeshöved & Dahmeshöved & 0.42 & 1600 & & & & 0.10 & 2071 \\
\hline 86.21 & Bliesdorf (north) & \multirow{2}{*}{ Bliesdorf } & \multirow{2}{*}{0.13} & \multirow{2}{*}{3000} & 0.73 & 0.96 & 460 & 0.16 & 1267 \\
\hline 86.21 & Bliesdorf (south) & & & & 0.23 & 0.62 & 1470 & 0.06 & 2237 \\
\hline 86.22 & Pelzerhaken & Pelzerhaken & & 1000 & 0.16 & 0.23 & 590 & 0.00 & 1054 \\
\hline 86.24 & Sierksdorf (north) & Wintershagen & 0.22 & 300 & 0.2 & 0.39 & 230 & 0.18 & 272 \\
\hline 86.24 & Sierksdorf (med) & \multirow{2}{*}{ Sierksdorf } & \multirow{2}{*}{0.12} & \multirow{2}{*}{1300} & 0.14 & 0.26 & 910 & 0.18 & 1445 \\
\hline 86.24 & Sierksdorf (south) & & & & 0.14 & 0.36 & 630 & 0.00 & 627 \\
\hline 86.28 & Brodten & Brodten & 0.43 & 4000 & 0.37 & 1.18 & 3420 & 0.58 & 4213 \\
\hline 500.03 & Strukkamphuk & & & & & & & 0.61 & 499 \\
\hline 500.05 & Albertsdorf & & & & 0.21 & 0.4 & 90 & 0.27 & 359 \\
\hline 500.24 & Marienleuchte & & & & 0.21 & 0.52 & 450 & 0.12 & 1253 \\
\hline 500.26 & Klausdorf & & & & 0.17 & 0.43 & 2360 & 0.13 & 2223 \\
\hline 500.26 & Katharinenhof & & & & 0.13 & 0.34 & 2480 & 10 & 2 \\
\hline 500.26 & Staberhof (east) & & & & 0.11 & 0.34 & 860 & 0.10 & 0000 \\
\hline 500.27 & Staberhdorf (south) & & & & 0.17 & 0.53 & 2400 & 0.07 & 3938 \\
\hline 500.32 & Wulfen & & & & 0.46 & 0.65 & 1020 & 0.19 & 986 \\
\hline Total & & & 0.22 & 47,400 & 0.24 & 1.18 & 57,140 & 0.19 & 85,493 \\
\hline
\end{tabular}




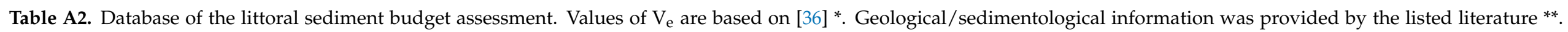

Calculations of $\mathrm{v}_{\mathrm{s}, \min }$ and $\mathrm{v}_{\mathrm{s}, \max }$ for sections with missing data for $\mathrm{n}$, $\mathrm{c}$ were based on $\mathrm{min} / \mathrm{max}$ estimates derived from local data (Table 2).

\begin{tabular}{|c|c|c|c|c|c|c|c|c|c|c|}
\hline Section No. & Location & $\begin{array}{c}\mathrm{V}_{\mathrm{e}} \\
\left(\mathrm{m}^{3} \mathrm{yr}-1\right) *\end{array}$ & $\begin{array}{c}v_{\mathrm{e}} \\
\left(\mathrm{m}^{3} \mathrm{yr}^{-1} \mathrm{~m}^{-1}\right)\end{array}$ & $\begin{array}{c}v_{\mathrm{s}, \min } \\
\left(\mathrm{m}^{3} \mathrm{yr}^{-1} \mathrm{~m}^{-1}\right)\end{array}$ & $\begin{array}{c}v_{\mathrm{s}, \max } \\
\left(\mathrm{m}^{3} \mathrm{yr}^{-1} \mathrm{~m}^{-1}\right)\end{array}$ & $\operatorname{nmin}(\%)$ & $\operatorname{nmax}(\%)$ & $\begin{array}{c}\text { cmin } \\
(\%)\end{array}$ & $\operatorname{cmax}(\%)$ & Literature ${ }^{* *}$ \\
\hline 81.05 & Solitüde & 158 & 1.44 & 0.17 & 1.96 & & & & & \\
\hline 81.08 & Holnis (west) & 963 & 4.01 & 0.48 & 5.47 & & & & & \\
\hline 81.08 & Holnis (north) & 134 & 0.56 & 0.07 & 0.76 & & & & & \\
\hline 81.08 & Holnis (east) & 199 & 0.71 & 0.09 & 0.97 & & & & & \\
\hline 81.1 & Langballigholz & 759 & 2.30 & 0.34 & 2.91 & & & 0.10 & 0.10 & [23] \\
\hline 81.12 & Neukirchen & 620 & 2.00 & 0.24 & 2.72 & & & & & \\
\hline 81.12 & Nieby & 678 & 1.44 & 0.21 & 1.84 & & & 0.09 & 0.10 & [23] \\
\hline 81.12 & Habernis (west) & 447 & 1.31 & 0.19 & 1.71 & & & 0.07 & 0.10 & [23] \\
\hline 81.13 & Habernis (east) & 1825 & 3.09 & 0.46 & 4.03 & & & 0.07 & 0.10 & [23] \\
\hline 81.13 & Steinberghaff & 303 & 0.35 & 0.05 & 0.45 & & & 0.09 & 0.12 & {$[23,85]$} \\
\hline 81.13 & Koppelheck & 55 & 0.29 & 0.03 & 0.39 & & & & & [85] \\
\hline 82.03 & Haffskoppel & 658 & 0.78 & 0.12 & 1.02 & & & 0.07 & 0.07 & [23] \\
\hline 82.08 & Schönhagen & 8960 & 4.77 & 3.24 & 4.57 & 0.50 & 0.50 & 0.04 & 0.09 & {$[11,23,28,54,86]$} \\
\hline 82.14 & Booknis & 2933 & 1.46 & 0.21 & 1.88 & & & 0.08 & 0.12 & [23] \\
\hline 83.01 & Waabs & 7963 & 3.72 & 0.55 & 5.07 & & & 0.03 & 0.11 & [23] \\
\hline 83.02 & $\begin{array}{l}\text { Hemmel- } \\
\text { mark }\end{array}$ & 1343 & 2.10 & 0.27 & 2.86 & & & 0.03 & 0.23 & {$[23,40]$} \\
\hline 83.06 & Schnellmark & 1964 & 2.18 & 0.32 & 2.89 & & & 0.06 & 0.10 & {$[23,87]$} \\
\hline \multirow{3}{*}{83.07} & \multirow{3}{*}{ Noer } & \multirow{3}{*}{3072} & 2.29 & 0.32 & 2.35 & 0.50 & 0.50 & 0.06 & 0.09 & \multirow{3}{*}[23,31,41]{} \\
\hline & & & 2.29 & 1.07 & 1.91 & 0.43 & 0.56 & 0.06 & 0.09 & \\
\hline & & & 2.29 & 1.39 & 4.26 & & & & & \\
\hline 83.07 & Krusendorf & 2583 & 3.44 & 0.49 & 4.47 & & & 0.07 & 0.14 & {$[23,31,40]$} \\
\hline
\end{tabular}


Table A2. Cont.

\begin{tabular}{|c|c|c|c|c|c|c|c|c|c|c|}
\hline Section No. & Location & $\begin{array}{c}\mathrm{V}_{\mathrm{e}} \\
\left(\mathrm{m}^{3} \mathrm{yr}-1\right)^{*}\end{array}$ & $\begin{array}{c}\mathrm{ve}_{\mathrm{e}} \\
\left(\mathrm{m}^{3} \mathrm{yr}^{-1} \mathrm{~m}^{-1}\right)\end{array}$ & $\left(\mathrm{m}^{3} \mathrm{yr}^{-1} \mathrm{~m}^{-1}\right)$ & $\left(\mathrm{m}^{3} \mathrm{yr}^{-1} \mathrm{~m}^{-1}\right)$ & $\mathrm{nmin}(\%)$ & $\operatorname{nmax}(\%)$ & $\underset{(\%)}{\mathrm{cmin}}$ & $\operatorname{cmax}(\%)$ & Literature ${ }^{* *}$ \\
\hline 83.07 & Dänisch-Nienhof & 1871 & 4.25 & 0.61 & 5.48 & & & 0.08 & 0.13 & {$[23,31]$} \\
\hline \multirow{3}{*}{83.08} & \multirow{3}{*}{ Stohl } & \multirow{3}{*}{15,076} & 4.14 & 0.21 & 1.40 & 0.13 & 0.57 & 0.04 & 0.17 & \multirow{3}{*}[23,26,31,41,55,56,88,89]{} \\
\hline & & & 4.14 & 1.53 & 2.65 & 0.43 & 0.48 & 0.04 & 0.17 & \\
\hline & & & 4.14 & 1.74 & 4.04 & & & & & \\
\hline 83.08 & Altbülk & 181 & 0.58 & 0.31 & 0.56 & 0.49 & 0.49 & & & [41] \\
\hline 85.01 & Stein & 1341 & 1.04 & 0.15 & 1.34 & & & 0.08 & 0.10 & {$[23,42]$} \\
\hline 85.04 & Todendorf & 10,568 & 2.57 & 0.35 & 3.33 & & & 0.07 & 0.18 & {$[23,90]$} \\
\hline 85.06 & Lippe & 46 & 0.26 & 0.03 & 0.35 & & & & & [90] \\
\hline 85.08 & Hohwacht & 745 & 1.73 & 0.26 & 2.31 & & & 0.05 & 0.10 & {$[23,42,90]$} \\
\hline 85.22 & Döhnsdorf & 2797 & 1.83 & 0.27 & 2.47 & & & 0.04 & 0.09 & {$[23,42]$} \\
\hline 85.12 & Wandelwitz & 3935 & 3.64 & 0.44 & 4.96 & & & & & \\
\hline 85.12 & Heiligenhafen & 4885 & 3.13 & 1.85 & 3.42 & 0.47 & 0.58 & 0.06 & 0.16 & {$[23,40,43,57]$} \\
\hline 86.01 & Lütjenbrode & 713 & 0.52 & 0.08 & 0.66 & & & 0.09 & 0.09 & {$[23]$} \\
\hline 86.07 & Heinrichsruh & 378 & 0.69 & 0.08 & 0.94 & & & & & \\
\hline 86.09 & Großenbrode & 906 & 1.28 & 0.15 & 1.24 & 0.11 & 0.50 & & & [47] \\
\hline 86.13 & Kraksdorf & 4874 & 1.64 & 0.25 & 2.20 & & & 0.04 & 0.09 & \\
\hline 86.21 & Bliesdorf (north) & 3391 & 7.37 & 1.11 & 9.47 & & & 0.08 & 0.09 & [23] \\
\hline 86.21 & Bliesdorf (south) & 3235 & 2.20 & 0.33 & 2.92 & & & 0.05 & 0.10 & [23] \\
\hline 86.22 & Pelzerhaken & 697 & 1.18 & 0.18 & 1.51 & & & 0.09 & 0.09 & [23] \\
\hline 86.24 & Sierksdorf (north) & 954 & 0.84 & 0.10 & 1.14 & & & & & \\
\hline 86.24 & Sierksdorf (south) & 1061 & 1.68 & 0.26 & 2.25 & & & 0.04 & 0.06 & [23] \\
\hline 86.28 & Brodten & 17,279 & 5.05 & 2.72 & 5.53 & 0.40 & 0.60 & 0.09 & 0.10 & {$[8,23,39,46,58]$} \\
\hline 500.05 & Albertsdorf & 61 & 0.68 & 0.10 & 0.87 & & & 0.08 & 0.08 & [23] \\
\hline
\end{tabular}


Table A2. Cont.

\begin{tabular}{|c|c|c|c|c|c|c|c|c|c|c|}
\hline Section No. & Location & $\begin{array}{c}\mathrm{V}_{\mathrm{e}} \\
\left(\mathrm{m}^{3} \mathrm{yr}-1\right) *\end{array}$ & $\begin{array}{c}v_{e} \\
\left(m^{3} \mathrm{yr}^{-1} \mathrm{~m}^{-1}\right)\end{array}$ & $\begin{array}{c}v_{s, \min } \\
\left(\mathrm{m}^{3} \mathrm{yr}^{-1} \mathrm{~m}^{-1}\right)\end{array}$ & $\begin{array}{c}v_{s, \max } \\
\left(\mathrm{m}^{3} \mathrm{yr}^{-1} \mathrm{~m}^{-1}\right)\end{array}$ & $\operatorname{nmin}(\%)$ & $\operatorname{nmax}(\%)$ & $\begin{array}{c}\mathrm{cmin} \\
(\%)\end{array}$ & $\operatorname{cmax}(\%)$ & Literature ** \\
\hline 500.24 & Marienleuchte & 303 & 0.67 & 0.08 & 0.92 & & & & & \\
\hline 500.26 & Klausdorf & 2137 & 0.91 & 0.11 & 1.19 & & & 0.06 & 0.27 & [23] \\
\hline 500.26 & $\begin{array}{l}\text { Katharinenhof } \\
\text { (Fehmarn) }\end{array}$ & 3115 & 1.26 & 0.48 & 1.04 & 0.34 & 0.48 & 0.13 & 0.23 & {$[23,47]$} \\
\hline 500.26 & Staberhuk (east) & 417 & 0.48 & 0.07 & 0.62 & & & 0.09 & 0.12 & [23] \\
\hline 500.32 & Wulfen & 3647 & 3.58 & 0.45 & 4.12 & & & 0.18 & 0.24 & {$[23,40]$} \\
\hline
\end{tabular}




\section{References}

1. Schwarzer, K. Sedimentdynamik in Sandriffsystemen Einer Tidefreien Küste Unter Berücksichtigung Von Rippströmen; Dissertation, Geologisch-Paläontologisches Institut und Museum der Universität Kiel: Kiel, Germany, 1989.

2. Hupfer, P.; Harff, J.; Sterr, H.; Stigge, H.J. Die Wasserstände an Der Ostsee. Entwicklung-Sturmfluten-Klimawandel. Küste 2003, $66,331$.

3. Davidson-Arnott, R.G.D. Introduction to Coastal Processes E Geomorphology; Cambridge University Press: Cambridge, UK, 2010; ISBN 9780521874458.

4. Hamann, M.; Klug, H. Sturmflutgefährdete Gebiete und potentielle Werteverluste an den Küsten Schleswig-Holsteins. Planungsgrundlagen für künftige Küstenschutzstrategien. Schr. Nat. Ver. Schlesw Holst 1997, 67, 17-28.

5. Ministerium für Energiewende, Landwirtschaft, Umwelt und ländliche Räume des Landes Schleswig-Holstein (MELUR). Generalplan Küstenschutz des Landes Schleswig-Holstein. Fortschreibung 2012. Available online: https:/ /www.schleswig-holstein. de/DE/Fachinhalte/K/kuestenschutz/Downloads/Generalplan.pdf\%3F_blob\%3DpublicationFile\%26v\%3D1 (accessed on 12 January 2021).

6. Oppenheimer, M.; Glavovic, B.C.; Hinkel, J.; van de Wal, R.; Magnan, A.K.; Abd-Elgawad, A.; Cai, R.; Cifuentes-Jara, M.; DeConto, R.M.; Ghosh, T.; et al. Sea Level Rise and Implications for Low-Lying Islands, Coasts and Communities. In IPCC Special Report on the Ocean and Cryosphere in a Changing Climate; Pörtner, H.-O., Roberts, D.C., Masson-Delmotte, V., Zhai, P., Tignor, M., Poloczanska, E., Mintenbeck, K., Alegría, A., Nicolai, M., Okem, A., Petzold, J., Rama, B., Weyer, N.M., Eds.; 2019 ; in press; p. 126.

7. Healy, T.; Wefer, G. The Efficacy of Submarine Abrasion vs Cliff Retreat as a Supplier of Marine Sediment in the Kieler Bucht, Western Baltic. Meyniana 1980, 32, 89-96.

8. Kannenberg, E.-G. Die Steilufer der Schleswig-Holsteinischen Ostseeküste. Probleme der marinen und klimatischen Abtragung. Schr. Geogr. Inst. Univ. Kiel 1951, 14, 101.

9. Amin, S.M.N.; Davidson-Arnott, R.G.D. A Statistical Analysis of the Controls on Shoreline Erosion Rates, Lake Ontario. J. Coast. Res. 1997, 13, 1093-1101.

10. Philpott, K.L. Comparison of cohesive coasts and beach coasts. In Proceedings, Coastal Engineering in Canada; Kamphuis, J.W., Ed.; USA Army Corps of Engineers. Coastal Engineering Manual. Engineer Manual 1110-2-1100; Army Corps of Engineers: Washington, DC, USA, 1984; pp. 227-244.

11. Schrottke, K. Rückgangsdynamik Schleswig-Holsteinischer Steilküsten Unter Besonderer Betrachtung Submariner Abrasion und Restsedimentmobilität. Dissertation; Kiel University: Kiel, Germany, 2001.

12. Terefenko, P.; Paprotny, D.; Giza, A.; Morales-Nápoles, O.; Kubicki, A.; Walczakiewicz, S. Monitoring Cliff Erosion with LiDAR Surveys and Bayesian Network-Based Data Analysis. Remote Sens. 2019, 11, 843. [CrossRef]

13. Richter, H.-C. Einfluß Der Material-Und Verbandseigenschaften Sowie Des Unterirdischen Wassers Auf Die Geschiebemergelsteilufer Der Ostküste. Mitt. Forsch. Schiffahrt Wasser Grundbau Schr. Wasser Grundbau 1989, 54, 92-103.

14. Sunamura, T. Geomorphology of Rocky Coasts; John Wiley \& Son: Chichester, NY, USA, 1992; Volume 3.

15. Walker, H.J. Bluff erosion at Barrow and Wainwright, Artic Alaska. In Z. Geomorph. N. F., 81; Gebrüder Borntraeger: Stuttgart, Germany, 1991; pp. 53-61.

16. Davidson-Arnott, R.G.D.; Ollerhead, J. Nearshore Erosion on a Cohesive Shoreline. Mar. Geol. 1995, 122, 349-365. [CrossRef]

17. Sterr, H. Der Abbruch von Steilküsten in der südwestlichen Kieler Bucht-unter spezieller Berücksichtigung des Januarsturmes 1987. Küste 1989, 50, 45-54.

18. Dong, P.; Guzzetti, F. Frequency-Size Statistics of Coastal Soft-Cliff Erosion. J. Waterw. Port Coast. Ocean Eng. 2005, 131, 37-42. [CrossRef]

19. Hampton, M.A.; Griggs, G.B. Formation, Evolution, and Stability of Coastal Cliffs-Status and Trends; U. S. Geological Survey (USGS) Professional Paper 1963. Available online: https:/ /books.google.com.hk/books?hl=zh-CN\&lr=\&id=F8Ze3v9JrVkC\&oi=fnd\& pg=PR3\&dq=Formation, + Evolution, + and + Stability + of + Coastal + Cliffs $\% E 2 \% 80 \% 94$ Status + and + Trends $\% 3 B \&$ ots $=$ rRWErYrfM0 \&sig=fPk96NsD8F8w0IiJLATXDF4HBy4\&redir_esc=y\#v=onepage\&q=Formation \%2C\%20Evolution \%2C\%20and\%20Stability \% 20of $\% 20$ Coastal $\% 20$ Cliffs $\% E 2 \% 80 \% 94$ Status $\% 20$ and $\% 20$ Trends $\% 3 B \& f=$ false (accessed on 11 August 2021).

20. Seifert, G. Bestandsaufnahme Der Steilufer An Den Küsten Fehmarns Und Wagriens Mit Dem Versuch, Den Verbleib Des Abbruchmaterials Nachzuweisen. Report (Unpublished); WSA: Kiel, Germany, 1953.

21. Seifert, G. Die Steilufer als Materiallieferanten der Sandwanderung. Meyniana 1955, 4, 78-83.

22. Nichols, G. Sedimentology and Stratigraphy, 2nd ed.; Wiley-Blackwell: Chichester, UK, 2009; ISBN 9788578110796.

23. Glückert, G. Über den Kalkgehalt des Geschiebemergels der schleswig-holsteinischen Ostsee-Steilküste. Meyniana 1974, $25,15-19$.

24. Von Rönn, G.A.; Krämer, K.; Franz, M.; Schwarzer, K.; Reimers, H.-C.; Winter, C. Dynamics of Stone Habitats in Coastal Waters of the Southwestern Baltic Sea (Hohwacht Bay). Geosciences 2021, 11, 171. [CrossRef]

25. Petersen, M. Abbruch und Schutz der Steilufer an der Ostseeküste (Samland bis Schleswig-Holstein). Küste 1952, 1, 100-152.

26. Niedermeyer, R.O.; Lampe, R.; Janke, W.; Schwarzer, K.; Duphorn, K.; Kliewe, H.; Werner, F. Die deutsche Ostseeküste; Sammlung Geologischer Führer, Gebr; Borntraeger: Stuttgart, Germany, 2011; Volume 105.

27. Seibold, E. Geological Investigation of Nearshore Sand-Transport-Examples of Methods and Problems from the Baltic and North Sea. Prog. Oceanogr. 1963, 1, 3-70. [CrossRef] 
28. Jannsen, J. Sedimentdynamik am Strand vor dem Schönhagener Kliff (Schleswig-Holstein). Diploma Thesis, Kiel University, Kiel, Germany, 1997.

29. Brooks, S.M.; Spencer, T. Temporal and Spatial Variations in Recession Rates and Sediment Release from Soft Rock Cliffs, Suffolk Coast, UK. Geomorphology 2010, 124, 26-41. [CrossRef]

30. Masselink, G.; Hughes, M.G. Introduction to Coastal Processes and Geomorphology; Edward Arnold: London, UK, 2003.

31. Prange, W. Gefügekundliche Untersuchungen der weichselzeitlichen Ablagerungen an den Steilufern des Dänischen Wohlds, Schleswig-Holstein. Meyniana 1987, 39, 85-110.

32. Dreimanis, A.; Lundqvist, J. What should be called till? Striae 1984, 20, 5-10.

33. Fleming, K.; Johnston, P.; Zwartz, D.; Yokoyama, Y.; Lambeck, K.; Chappell, J. Refining the Eustatic Sea-Level Curve since the Last Glacial Maximum Using Far- and Intermediate-Field Sites. Earth Planet. Sci. Lett. 1998, 163, 327-342. [CrossRef]

34. Schwarzer, K.; Reimers, H.-C.; Störtenbecker, M.; Von Waldow, K.-R. Das Küstenholozän in der westlichen Hohwachter Bucht. Meyniana 1993, 45, 131-144.

35. Landesbetrieb Für Küstenschutz, Nationalpark Und Meeresschutz Des Landes Schleswig-Holstein (LKN-SH). Fachplan Küstenschutz Ostseeküste. Grundlagen. Available online: https://www.schleswig-holstein.de/DE/Fachinhalte/K/kuestenschutz_ fachplaene/Ostseekueste/2_Grundlagen/2_0_grundlagen.html\#doc25f3538c-ce42-4123-93fd-3e4d85986168bodyText13 (accessed on 23 September 2020).

36. Ziegler, B.; Heyen, A. Rückgang der Steilufer an der schleswig-holsteinischen westlichen Ostseeküste. Meyniana 2005, 57, 61-92.

37. Bundesministerium für Verkehr, Bau und Stadtentwicklung (BMVBS). Digitale Bundeswasserstraßenkarte 1:2000 (DBWK 2); Bundesministerium für Verkehr, Bau und Stadtentwicklung (BMVBS): Berlin, Germany, 2003.

38. Gripp, K. Erdgeschichte von Schleswig-Holstein; Karl-Wachholtz-Verlag: Neumünster, Germany, 1964.

39. Dücker, A. Die Ursachen des Kliffrückgangs am Brodtener Ufer bei Travemünde. In Beiträge zur Landeskunde von Schleswig-Holstein; Schott, C., Ed.; Ferdinand Hirt: Kiel, Germany, 1953; pp. 38-53.

40. Kabel, C. Geschiebestratigraphische Untersuchungen im Pleistozän Schleswig-Holstein und angrenzender Gebiete. Ph.D. Dissertation, Kiel University, Kiel, Germany, 1982.

41. Livingstone, S.J.; Piotrowski, J.A.; Bateman, M.D.; Ely, J.C.; Clark, C.D. Discriminating between Subglacial and Proglacial Lake Sediments: An Example from Dänischer Wohld Peninsula, Northern Germany. Quat. Sci. Rev. 2015, 112, 86-108. [CrossRef]

42. Prange, W. Geologie der Steilufer zwischen Kieler Förde und Hohwachter Bucht. Schr. Nat. Ver. Schlesw Holst 1991, 61, 1-18.

43. Stephan, H.-J. Exkursionsführer Heiligenhafener "Hohes Ufer". Geschiebesammler 1985, 18, 83-99.

44. Stephan, H.-J. Der jungbaltische Gletschervorstoß in Norddeutschland. Schr. Nat. Ver. Schlesw Holst 1994, 64, 1-15.

45. Ehlers, J. Das Eiszeitalter; Springer: Berlin, Heidelberg, Germany, 2020.

46. Groschopf, P. Physikalische Bedingungen des Kliffrückganges an der Kieler und Lübecker Bucht. Kiel. Meeresforsch 1936, 1, 335-342.

47. Pour-Nagshsband, G.R. Tonmineralbestand und Baugrundeigenschaften der Tarras-Tone, Beckentone und des Geschiebemergels in Teilgebieten Schleswig-Holsteins. Meyniana 1978, 30, 55-60.

48. Picard, K. Der Einfluß der Tektonik auf das pleistozäne Geschehen in Schleswig-Holstein. Schr. Nat. Ver. Schlesw Holst 1964, 35, 99-113.

49. Köster, R. Die Küsten Der Flensburger Förde. Ein Beispiel Für Morphologie Und Entwicklung Einer Bucht. Schr. Nat. Ver. Schlesw Holst 1958, 29, 5-18.

50. Stephan, H.-J. Zur Entstehung der eiszeitlichen Landschaft Schleswig-Holsteins. Schr. Nat. Ver. Schlesw Holst 2003, $68,101-118$.

51. Kubisch, M.; Schönfeld, J. Eine neue "Cyprinen-Ton"-Scholle bei Stohl (Schleswig-Holstein): Mikrofauna und Grobfraktionsanalyse von Sedimenten der Eem-zeitlichen Ostsee. Meyniana 1985, 37, 89-95.

52. Landesbetrieb für Küstenschutz, Nationalpark und Meeresschutz des Landes Schleswig-Holstein (LKN-SH). Änderungsraten Obere Abbruchkante 1878-2016. Table (Unpublish); Landesbetrieb für Küstenschutz, Nationalpark und Meeresschutz des Landes Schleswig-Holstein (LKN-SH): Husum, Germany, 2019.

53. Wentworth, C.K. A Scale of Grade and Class Terms for Clastic Sediments. J. Geol. 1922, 30, 377-392. [CrossRef]

54. Weinhold, H. Untersuchungen am Ostsee-Steilufer bei Schönhagen. Landabtrag-Geologie und Ursachen. Ing. geol. Bericht (unpublished); Geologisches Landesamt Schleswig-Holstein: Kiel, Germany, 1989.

55. Wenghöfer, S. Die weichselzeitliche Entwicklung des Dänischen Wohlds im Bereich Stohl/Marienfelde. Quartärgeologische Kartierung und Kliffaufnahme. Diploma Thesis, Kiel University, Kiel, Germany, 1991.

56. Piotrowski, J.A. Till Facies and Depositional Environments of the Upper Sedimentary Complex from the Stohler Cliff, SchleswigHolstein, North Germany. Z. Geomorph. N. F. Supp. 1992, 84, 37-54.

57. Schlieker, M. Glazialgeologie des "Hohen Ufers” bei Heiligenhafen und des angrenzenden Gebietes. Diploma Thesis, Kiel University, Kiel, Germany, 1997, (1st part) (unpublished).

58. Dücker, A. Über die physikalischen Eigenschaften der das Brodtener Ufer aufbauenden Bodenarten und ihre Bedeutung für den Steiluferrückgang und Errichtung eines Uferschutzwerkes. Küste 1952, 2, 21-33.

59. Sunamura, T. Processes of sea cliff and platform erosion. In Handbook of Coastal Processes and Erosion; Komar, P.D., Ed.; CRC Press: Boca Raton, FL, USA, 1983; pp. 233-265.

60. Bray, M.J.; Hooke, J.M. Prediction of Soft-Cliff Retreat with Accelerating Sea-Level Rise. J. Coast. Res. 1997, $13,453-467$. 
61. Hünicke, B.; Zorito, E.; von Storch, H. The Challenge of Baltic Sea-level Change. In Coastline Changes of the Baltic Sea from South to East. Past and Future Projection; Harff, J., Furmańczyk, K., von Storch, H., Eds.; Springer International Publishing: Berlin, Germany, 2017; Volume 19, pp. 37-54, ISBN 9783319842660.

62. Köntje, L. Vorstrand-und Uferveränderungen an der Schleswig-Holsteinischen Ostseeküste über Zwei Dekaden (1980-2000). Master's Thesis, Kiel University, Kiel, Germany, 2015.

63. Ministerium für Landwirtschaft, Umwelt und Ländliche Räume des Landes Schleswig-Holstein (MLUR-SH). Landesverordnung über Gesetzlich Geschützte Biotope (Biotopverordnung). Available online: https:/ / www.gesetze-rechtsprechung.sh.juris.de/ jportal/?quelle=jlink\&query=BiotopV+SH\&psml=bsshoprod.psml\&max=true (accessed on 5 July 2021).

64. Flemming, B.; Wefer, G. Tauchbeobachtungen an Wellenrippeln und Abrasionserscheinungen in der Westlichen Ostsee südöstlich Bokniseck. Meyniana 1973, 23, 9-18.

65. Köster, R.; Schwarzer, K. Geologische Untersuchungen zur Sandvorspülung vor der Probstei/Ostsee; Geologisch-Paläontologisches Institut und Museum der Universität Kiel: Kiel, Germany, 1988; p. 113.

66. Amt für Land-und Wasserwirtschaft Kiel; Leichtweiss-Institut für Wasserbau der TU Braunschweig; Geologisch-Paläontologisches Institut der Univ. Kiel. In KFKI-Forschungsvorhaben "Vorstranddynamik Einer Tidefreien KÜSTE", Förderkennzeichen: MTK 0494; Uni Kiel: Kiel, Germany, 1997; p. 232.

67. Simmer, K. Grundbau 1: Bodenmechanik Und Erdstatische Berechnungen, 19th ed.; Benedictus Gotthelf Teubner: Stuttgart, Germany, 2012.

68. Ministerium Für Landwirtschaft, Umwelt Und Verbraucherschutz Mecklenburg-Vorpommern. Regelwerk Küstenschutz Mecklenburg-Vorpommern. Available online: http:/ / www.stalu-mv.de/mm/Themen/K\%C3\%BCstenschutz/Regelwerk-K\% C3\%BCstenschutz-Mecklenburg\%E2\%80\%93Vorpommern/ (accessed on 2 March 2021).

69. Ministerium für Energiewende, Landwirtschaft, Umwelt und Ländliche Räume des Landes Schleswig-Holstein Fachplan Küstenschutz Ostseeküste: Zahlen Daten Fakten. Available online: https://www.schleswig-holstein.de/DE/Landesregierung/ V/Presse/PI/PDF/2014/Fachplan_Kuestenschutz.pdf?_blob=publicationFile\&v=2 (accessed on 23 November 2020).

70. Schnick, H.H. Zur Morphogenese der Steilufer Ost-Jasmund (Insel Rügen)—eine landschaftsgeschichtliche Betrachtung. Z. Geol. Wiss. Berl. 2006, 34, 73-97.

71. Ministerium für Bau, Landesentwicklung und Umwelt Mecklenburg-Vorpommern. Generalplan Küsten-und Hochwasserschutz Mecklenburg-Vorpommern. Available online: http://www.stalu-mv.de/mm/Themen/K\%C3\%BCstenschutz/GeneralplanK\%C3\%BCsten\%E2\%80\%93-und-Hochwasserschutz-Mecklenburg\%E2\%80\%93Vorpommern-1993/ (accessed on 10 March 2021).

72. Kolander, R.; Morche, D.; Bimböse, M. Quantification of Moraine Cliff Coast Erosion on Wolin Island (Baltic Sea, Northwest Poland). Baltica 2013, 26, 37-44. [CrossRef]

73. Dudzińska-Nowak, J.; Wężyk, P. Volumetric Changes of a Soft Cliff Coast 2008-2012 Based on DTM from Airborne Laser Scanning (Wolin Island, Southern Baltic Sea). J. Coast. Res. 2014, SI 70, 59-64. [CrossRef]

74. Landesbetrieb für Küstenschutz, Nationalpark und Meeresschutz des Landes Schleswig-Holstein (LKN-SH). Fachplan Küstenschutz Ostseeküste. Bisheriger Küstenschutz. Available online: https://www.schleswig-holstein.de/DE/Fachinhalte/K/ kuestenschutz_fachplaene/Ostseekueste/3_BishKuestenschutz/3_0_bisherig.html (accessed on 11 August 2021).

75. Jibson, R.W.; Staude, J.M. Bluff Recession Rates along the Lake Michigan Shoreline in Illinois. Bull. Assoc. Eng. Geol. 1992, 29, 103-117. [CrossRef]

76. Amin, S.M.N.; Davidson-Arnott, R.G.D. Toe Erosion of Glacial till Bluffs: Lake Erie South Shore. Can. J. Earth Sci. 1995, 32, 829-837. [CrossRef]

77. Davidson-Arnott, R.G.D.; Amin, S.M.N. An Approach to the Problem of Coastal Erosion in Quaternary Sediments. Appl. Geogr. 1985, 5, 99-116. [CrossRef]

78. Meadows, G.A.; Mackey, S.D.; Goforth, R.R.; Mickelson, D.M.; Edil, T.B.; Fuller, J.; Guy, D.E.; Meadows, L.A.; Brown, E.; Carman, S.M.; et al. Cumulative Habitat Impacts of Nearshore Engineering. J. Gt. Lakes Res. 2005, 31, 90-112. [CrossRef]

79. Gurwell, B. Grundsätzliche Anmerkungen zur langfristigen Abrasionswirkung und ihrer Quantifizierung. Mitt Forsch. Schifffahrt Wasser Grundbau Berl 1989, 54, 22-39.

80. Wefer, G.; Flemming, B.; Kiel, T. Submarine Abrasion des Geschiebemergels vor Bokniseck (Westl. Ostsee). Meyniana 1976, $28,87-94$.

81. Schrottke, K.; Schwarzer, K.; Fröhle, P. Mobility and Transport Directions of Residual Sediments on Abrasion Platforms in Front of Active Cliffs (Southwestern Baltic Sea). J. Coast. Res. 2006, SI 39, 459-464.

82. Kasten, S. Der Erosive Einfluss von Sedimentbedeckung, Morphologie und Bioturbation auf Verschiedene Abrasionsplattformen in der Kieler und Lübecker Bucht. Diploma Thesis, Kiel University, Kiel, Germany, 2012, (unpublished).

83. Schwarzer, K.; Bohling, B.; Heinrich, C. Submarine Hard-Bottom Substrates in the Western Baltic Sea-Human Impact versus Natural Development. J. Coast. Res. 2014, SI 70, 145-150. [CrossRef]

84. Dette, H.H.; Manzenrieder, H. Modelluntersuchungen Zur Optimierung Von Deichprofilen Und Buhnensystemen Vor Der Probstei; Leichtweiss-Institut für Wasserbau Der Technischen Universität Braunschweig: Braunschweig, Germany, 1979.

85. Exon, N.F. An Extensive Offshore Sand Bar Field in the Western Baltic Sea. Mar. Geol. 1975, 18, 197-212. [CrossRef]

86. Walther, M.; Grossmann, M. Das Schönhagener "Head"-Kliff an der Ostseeküste Schwansens (Schleswig-Holstein). Geogr. Oekologica 1991, 4, 1-83. 
87. Prange, W. Glazialgeologische Aufschlußuntersuchung im weichselzeitlichen Vereisungsgebiet zwischen Schleswig und Kiel. Meyniana 1990, 42, 65-92.

88. Piotrowski, J. Dynamik Und Subglaziale Paläohydrogeologie Der Weichselzeitlichen Eiskappe in Zentral-Schleswig-Holstein; GeologischPaläontologisches Institut der Universität Kiel: Kiel, Germany, 1996; p. 188.

89. Piotrowski, J.A.; Döring, U.; Harder, A.; Qadirie, R.; Wenghöfer, S. “Deforming Bed Conditions on the Dänischer Wohld Peninsula, Northern Germany": Comments. Boreas 1997, 26, 73-77. [CrossRef]

90. Ernst, T. Die Hohwachter Bucht: Morphologsiche Entwicklung Einer Küstenlandschaft. Schr. Nat. Ver. Für Schlesw Holst 1974, $44,47-96$. 